\title{
THE CHRONOLOGY OF PLEISTOCENE MODERN HUMANS IN CHINA, KOREA, AND JAPAN
}

S G Keates

Email: archres2009@googlemail.com.

\begin{abstract}
The chronological status of Pleistocene fossils of early modern humans in the People's Republic of China is based almost exclusively on indirect dating of the stratigraphic context and faunal and radiocarbon dating of associated or supposedly associated archaeological specimens. A similar pattern is observed in Korea and Japan. This paper examines the ${ }^{14} \mathrm{C}$ and other dating techniques of early modern humans in East Asia to gain a more complete and up-to-date understanding of their chronology.
\end{abstract}

\section{INTRODUCTION}

Most early modern Homo sapiens fossils of Pleistocene or presumed Pleistocene age in East Asia are from the People's Republic of China (PR China), while far fewer have been found in Japan and Korea. The reasons for this are the larger land area of PR China (the third largest country in the world) and the greater length of Pleistocene archaeological research in China, and, perhaps equally important, the more favorable sedimentary conditions in this country. There are 46 localities with early modern $H$. sapiens fossils in China. The majority is dated by means of stratigraphic and/or faunal assessments. A similar pattern can be observed in Korea and Japan. Korea has 7 sites and Japan 16 (Table 1). In this paper, I include all sites that have yielded Pleistocene fossils attributed to early modern humans to document the number of dated and undated sites. Some human fossils may be earlier than late Late Pleistocene, while others could date to the Holocene. The number and kind of human fossils are also given to show the direct dating potential available (subject to preservation).

Table 1 Summary of Pleistocene modern human sites and dating frequencies in East Asia.

a) Sites with Pleistocene modern humans:

China: 46

Korea: 7

Japan: 16

b) Sites with Pleistocene modern humans with ${ }^{14} \mathrm{C}$ and U-series dates on associated materials with known context:

China: 25

Korea: 5

Japan: 5

c) Sites with Pleistocene modern humans with direct ${ }^{14} \mathrm{C}$ dates:

China: 1

Korea: 0

Japan: 2

Two major sources are used for the Chinese sites: the compilation of human fossils by Wu and Poirier (1995) and the compilation of radiocarbon dates by The Institute of Archaeology, Chinese Academy of Social Sciences, the latter henceforth referred to as CASS (1991). The latter includes the majority of ${ }^{14} \mathrm{C}$ dates performed on Chinese sites. The dating was conducted by several laboratories, e.g. the ${ }^{14} \mathrm{C}$ Laboratory, Peking University; the ${ }^{14} \mathrm{C}$ Laboratory, the Institute of Vertebrate Paleontology and Paleoanthropology; and the Laboratory of the Institute of Archaeology, Chinese Academy of Social Sciences, Academia Sinica; all in Beijing. Original sources were consulted when available. ${ }^{14} \mathrm{C}$ dating has been practiced in China since 1965 (with the first results published in 1972: Barnard 1972; An 1991) and accelerator mass spectrometry (AMS) ${ }^{14} \mathrm{C}$ dating results are known since 1998

(C) 2010 by the Arizona Board of Regents on behalf of the University of Arizona Proceedings of the 20th International Radiocarbon Conference, edited by A J T Jull RADIOCARBON, Vol 52, Nr 2-3, 2010, p 428-465 
(Zhou and Chen 2009). Uranium-series dates of hominid sites are also presented. For geographic orientation of sites, I have consulted the Atlas of the People's Republic of China (Yang 1989).

\section{OVERVIEW OF CURRENT DATA}

\section{CHINA}

In China, the 46 identified sites with modern human fossils are categorized in this paper according to whether they have directly dated human fossils, indirectly dated human fossils (i.e. chronologically assessed with reference to the stratigraphy and/or fauna), and those without any radiometric dates. One of these sites is problematic in regard to the human status of the fossil (Longtanshan site 2). Another site, based on recent direct dating, is not of Pleistocene age (Xarus), but is also included in this paper.

Hominid finds in China are usually named after the county they were found in (e.g. Wu and Poirier 1995). In this paper, whenever possible, the local site names are given with the conventional site names in brackets. Chinese anthropologists classify archaic Homo sapiens fossils as early Homo sapiens, an intermediate grade between Homo erectus and anatomically modern $\mathrm{H}$. sapiens, and modern H. sapiens as late H. sapiens (e.g. Zhang 1986). This paper is a review of East Asian modern humans from Pleistocene or assumed Pleistocene contexts. The majority of fossils classified as Pleistocene modern H. sapiens from China are teeth (see e.g. Wu and Poirier 1995).

\section{Directly Dated Human Fossil Sites}

The only directly dated early modern human fossil in China was excavated at the cave site of Tianyuandong near Zhoukoudian, Fangshan County (Shang et al. 2007; see Figure 1). Parts of a human skeleton (Tianyuandong I, 34 cranial and post-cranial elements) were mostly found in layer 3 (of a total of 4 layers) and some in a disturbed area; 39 mammalian species (including Martes sp., Ursus thibetanus, Tong et al. 2004) were associated with the human remains in the 0.75-m-thick clay with breccia layer. The 6 AMS ${ }^{14} \mathrm{C}$ dates on animal bones and a human femur from layer 3 range from 30,500 \pm 370 to 39,430 $\pm 680 \mathrm{BP}$ (Tong et al. 2006) with Tianyuan I occupying an intermediary date of $\sim 34,000$ BP (Shang et al. 2007; see Table 3).

\section{Indirectly Dated Human Fossil Sites}

\section{Shandingdong (Upper Cave)}

The most prominent site in China is Zhoukoudian near Beijing. Zhoukoudian is in fact a complex of early to late Middle Pleistocene and late Late Pleistocene limestone sites (e.g. Jia and Huang 1990; Figure 1). Shandingdong, or Upper Cave, was discovered in 1930 during excavations of the Homo erectus site of Zhoukoudian Locality 1 . A trial excavation in 1930 was followed by excavations in 1933 and 1934 (Jia and Huang 1990; and see Jia 1999). Animal and human bones were found in the Entrance, the Upper Room, and the Lower Room (Pei 1939; also see Wu and Poirier 1995:165-6). A small number of human bones and artifacts derive from layer 1 close to the Entrance. The Upper Room with its 3 cultural layers, layers 1-3, contained a small number of human bones and a large collection of perforated animal teeth are from layer 2; layer 3 yielded a small number of artifacts and indications of burning (Pei 1934, 1939). The main collection of human fossils was found in the Lower Room in layers 4 and 5 (depth $>5 \mathrm{~m}$ ), including cranial and post-cranial fossils of $H$. sapiens (including a skull and 2 crania); a lithic artifact, perforated teeth, and bone ornaments were also recovered (Pei 1939). 


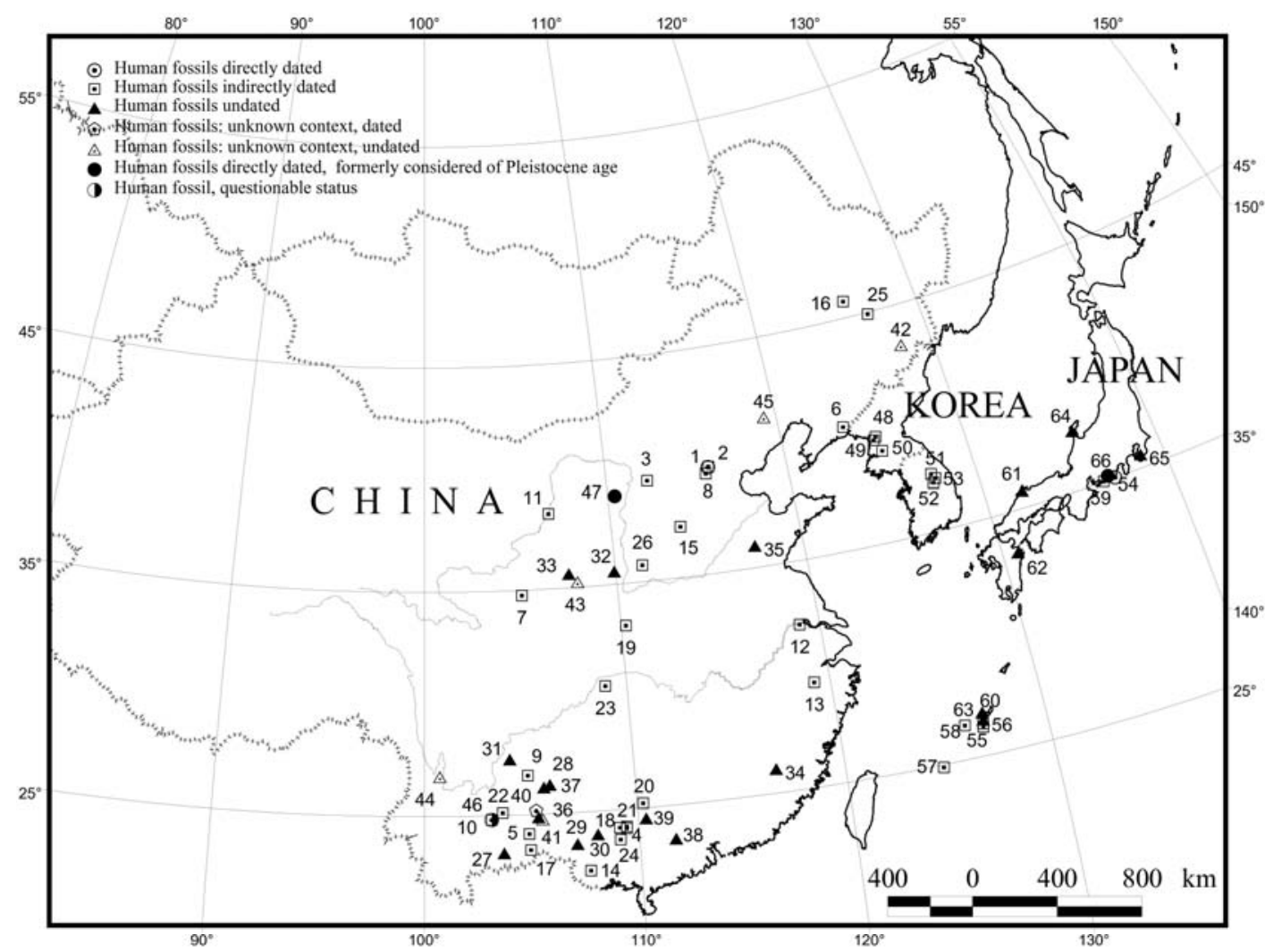

Figure 1 Distribution of modern human fossil sites in East Asia. A: Human fossils directly dated: 1. Tianyuandong; 54. Negata. B: Human fossils indirectly dated: 2. Shandingdong; 3. Shiyu; 4. Tongtianyan; 5. Huangshanxi; 6. Miaohoushan Dongdong; 7. Yuanyang; 8. Laishui; 9. Xiaohuidong; 10. Longtanshan Site 1; 11. Shuidonggou; 12. Lianhuadong; 13. Wuquidong; 14. Nanshandong; 15. Dangcheng; 16. Yanjiagang; 17. Xianrendong; 18. Ganqian; 19. Huanglongdong; 20. Baojiyandong; 21. Bailiandong; 22. Zhangkoudong; 23. Migongdong Locality 4; 24. Gaitoudong; 25. Site H8601; 26. Chaoyang Xigou; 48. Mandalli; 49. Ryonggok; 50. Kumchon; 51. Chommal; 52. Sangsi and Hungsugul; 53. Kunanggul; 55. Minatogawa and Upper Minatogawa; 56. Yamashita-cho Cave 1; 57. Pinza-abu; 58. Shimojibaru; 59. Ushikawa. C: Human fossils undated: 27. Maludong; 28. Chuandong; 29. Dingmo; 30. Cave R5013; 31. Guoshandong; 32. Huanglong; 33. Niujiagou; 34. Hulidong; 35. Wuzhutai; 36. Nalai; 37. Taohua; 38. Dongzhongyan; 39. Shuiyan Dongdong; 60. Kadabaru and Gohezu; 61. Yomigahama; 62. Hijiridake Cave; 63. Tobaru and Oyama; 64. Tomari Cave; 65. Kuzuü. D: Human fossils unknown context, dated: 40. Maomaodong. E: Human fossils unknown context, undated: 41. Longlin; 42. Antu; 43. Changwu; 44. Mujiajiao; 45. Jianpin. F: Human fossils, directly dated, formerly considered of Pleistocene age: 47. Xarus; 66. Mikkabi. G: Human fossil, questionable status: 46. Longtanshan Site 2.

The modern human fossil collection from Shandingdong (also including a maxilla fragment, 4 mandibles, 3 mandible fragments, many teeth, and about 32 post-cranial bones) is representative of a mininum number of individuals (MNI) of 8 (Wu 1961). There are 46 species of mammals (including Crocuta ultima, Elephas sp.) from Shandingdong (Wu and Poirier 1995:166-8).

${ }^{14} \mathrm{C}$ dating places the lower limit of the cultural layers at 10,000 BP (CASS 1991:17), while the upper limit of these layers is about 24,000-29,000 BP (e.g. Chen et al. 1992). A U-series date for a cultural layer is 19,000 yr old (Chen et al. 1984; Table 3). As Kamminga and Wright (1988) with reference to An (1983) point out, sample ZK-0136(2) is from layer 5, and therefore earlier than layer 4. Although Wu and Wang (1985) argue that samples ZK-136-0 and -0136(2) (ZK-136-0(1) and 136-0(2) in Wu and Wang 1985; Table 2) were recovered from below the archaeological layers, the labels on the bones identify the provenance as layer 4 (Kamminga and Wright 1988; Table 3). 


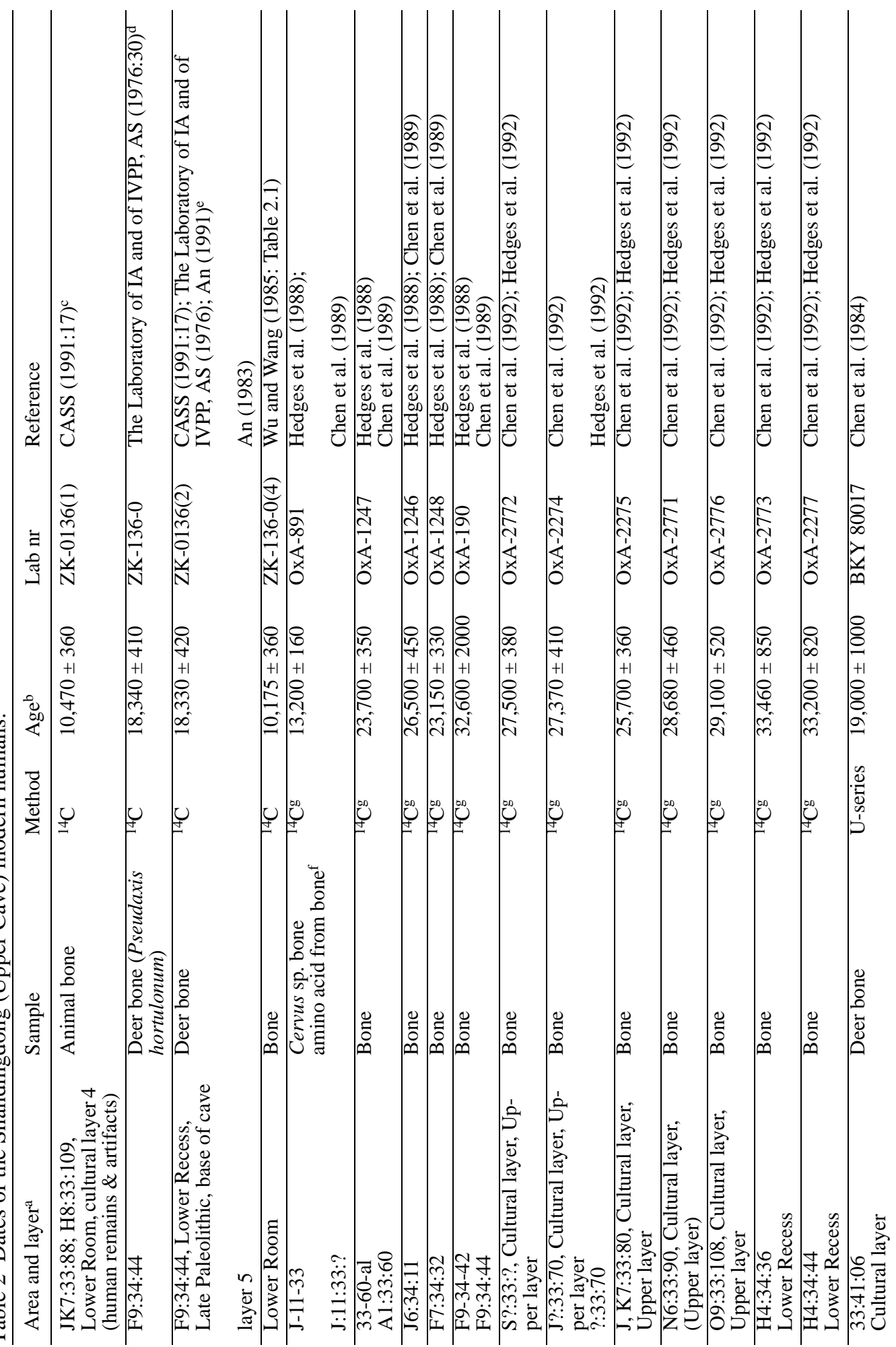




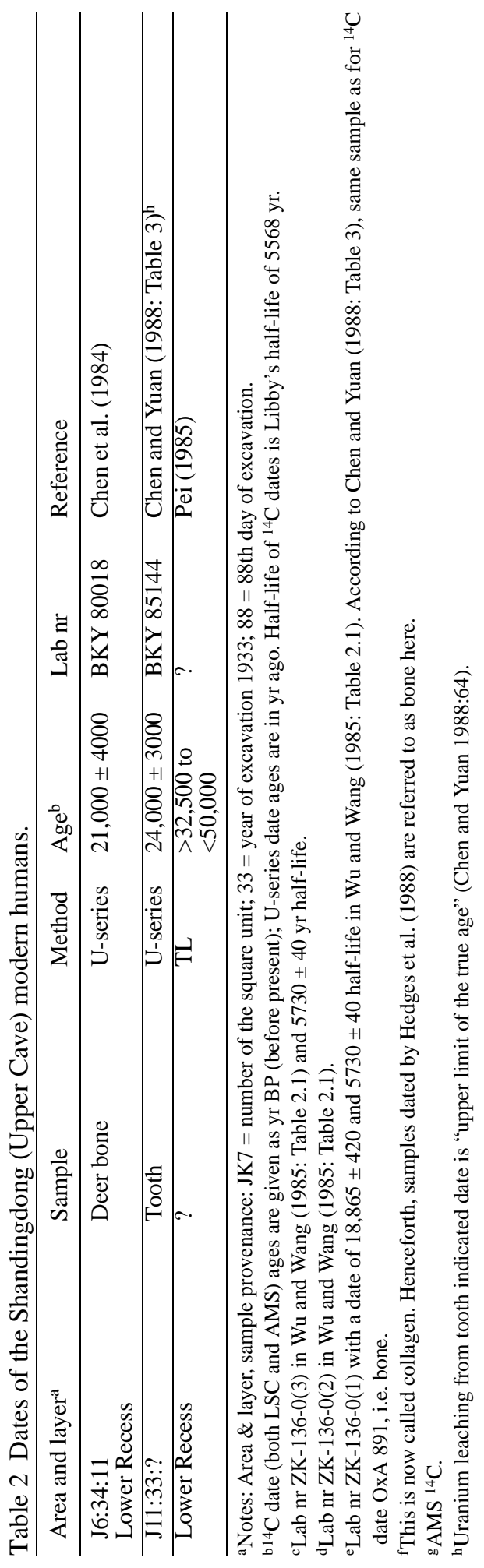




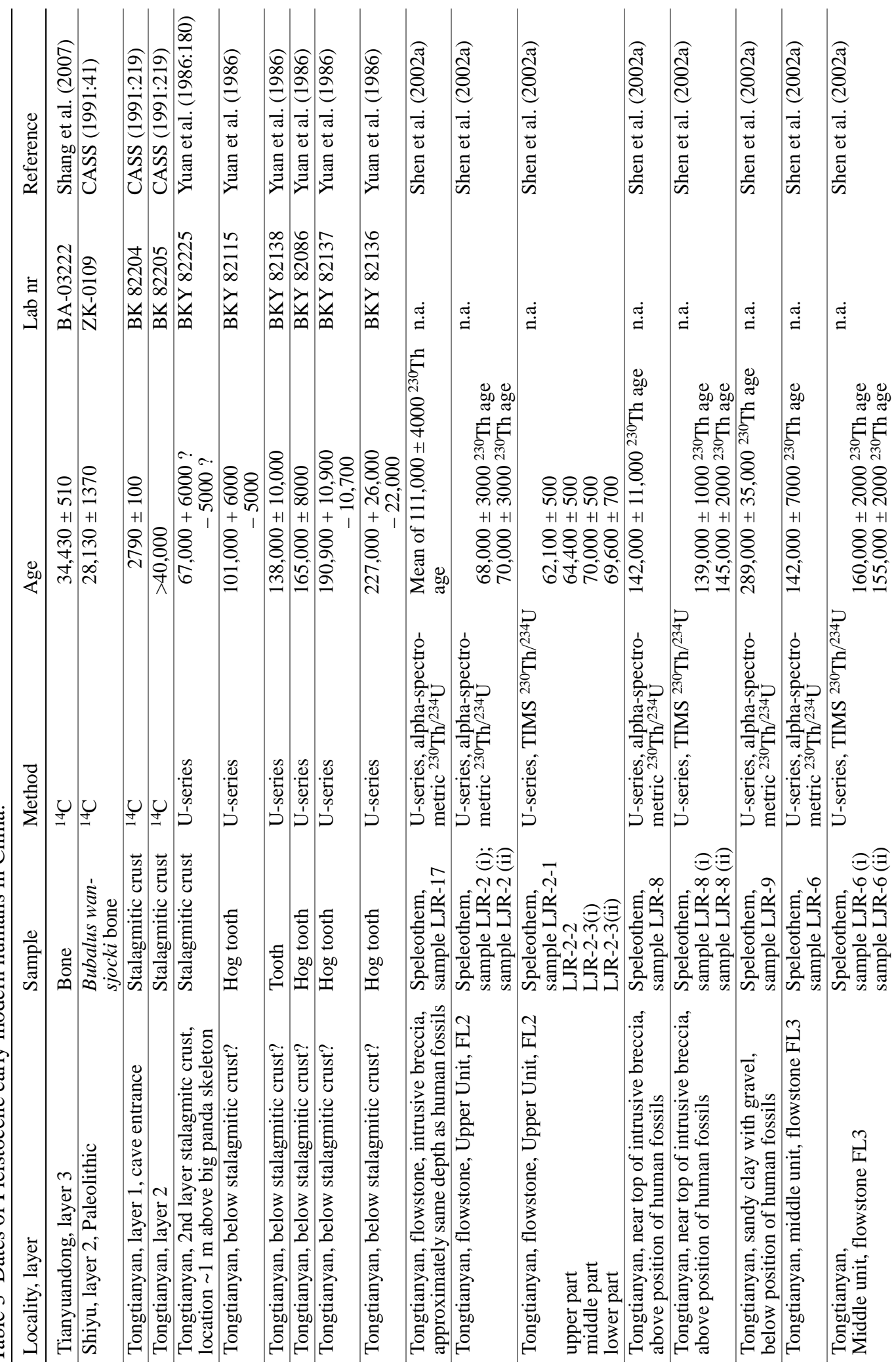




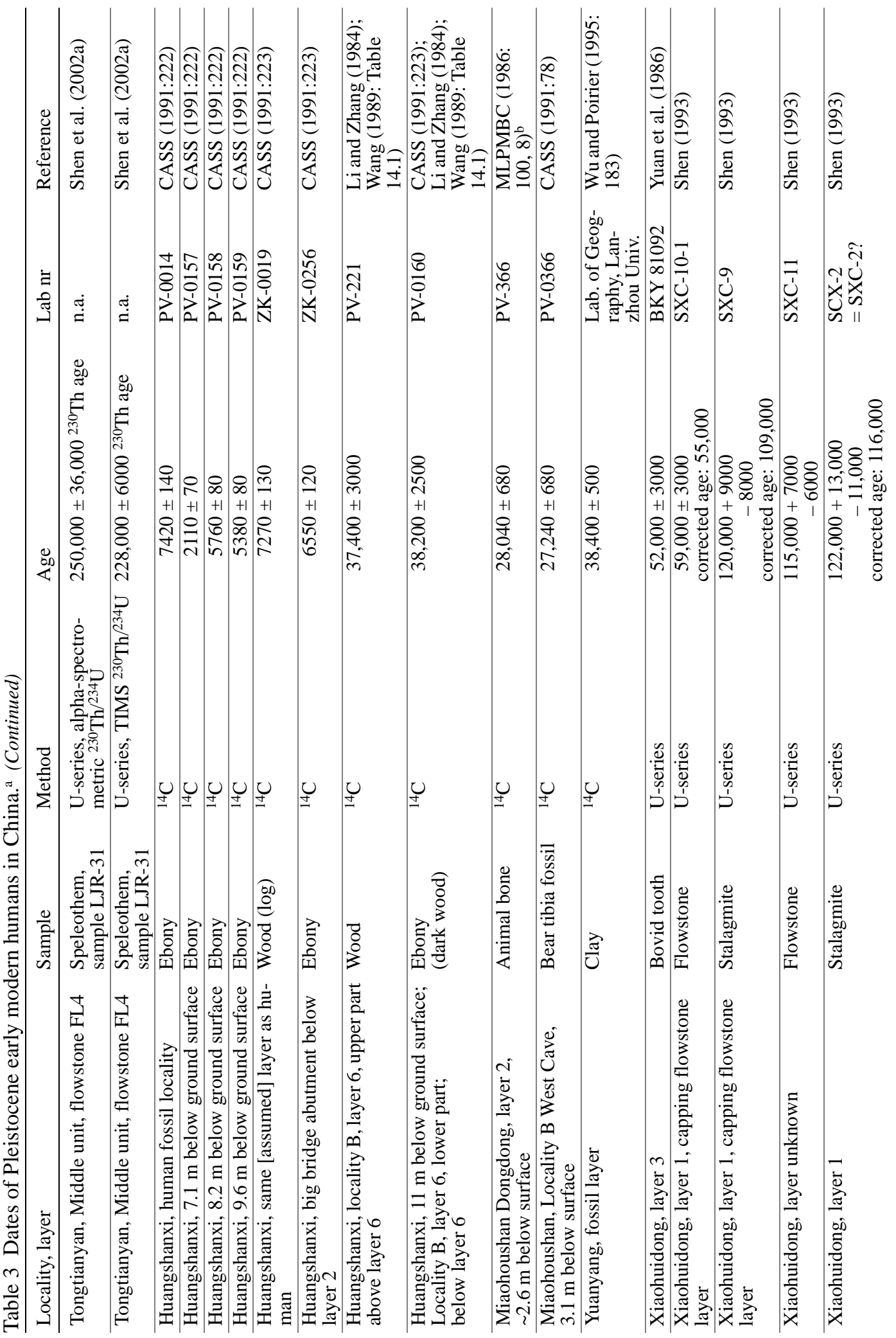




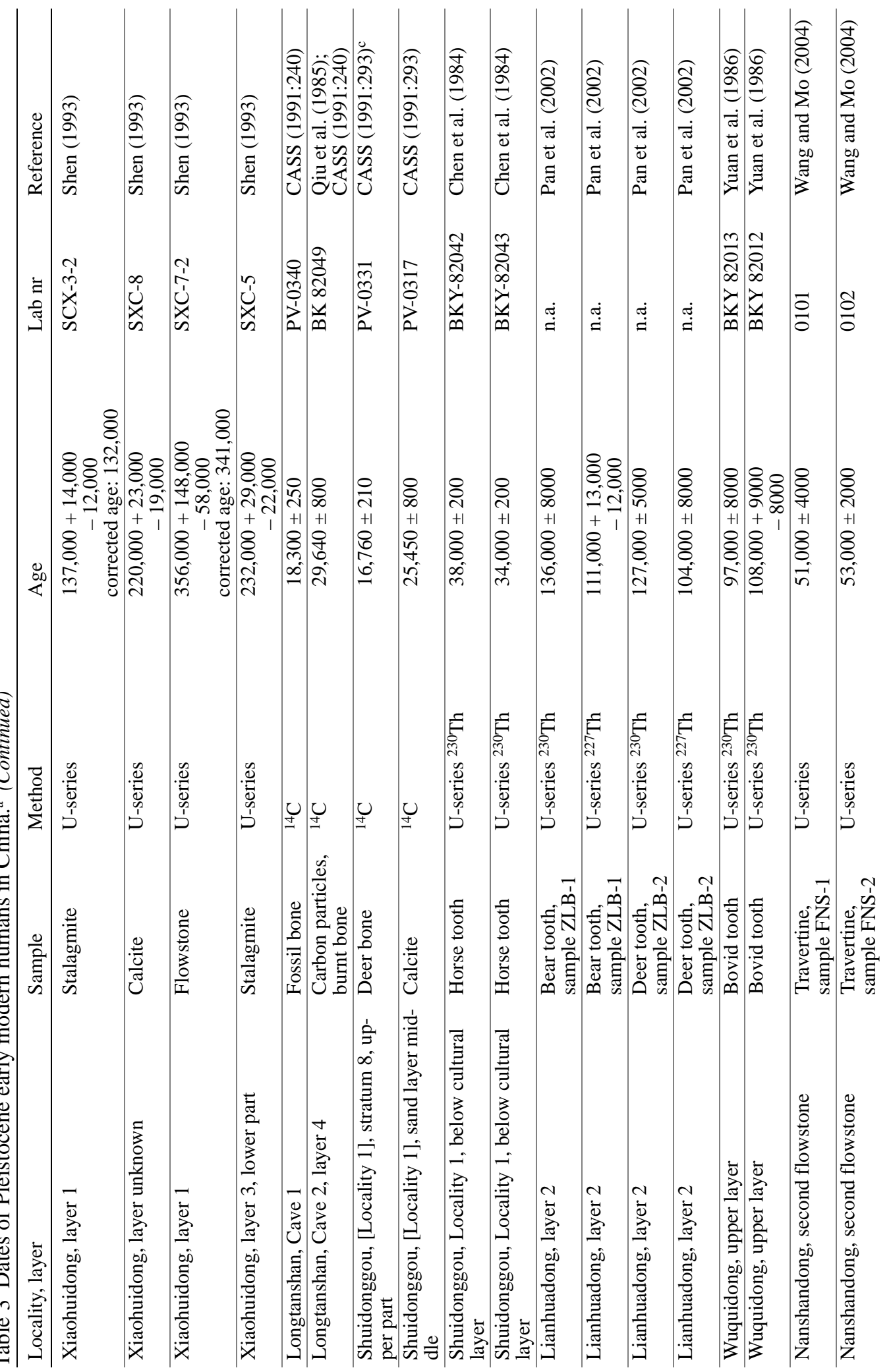




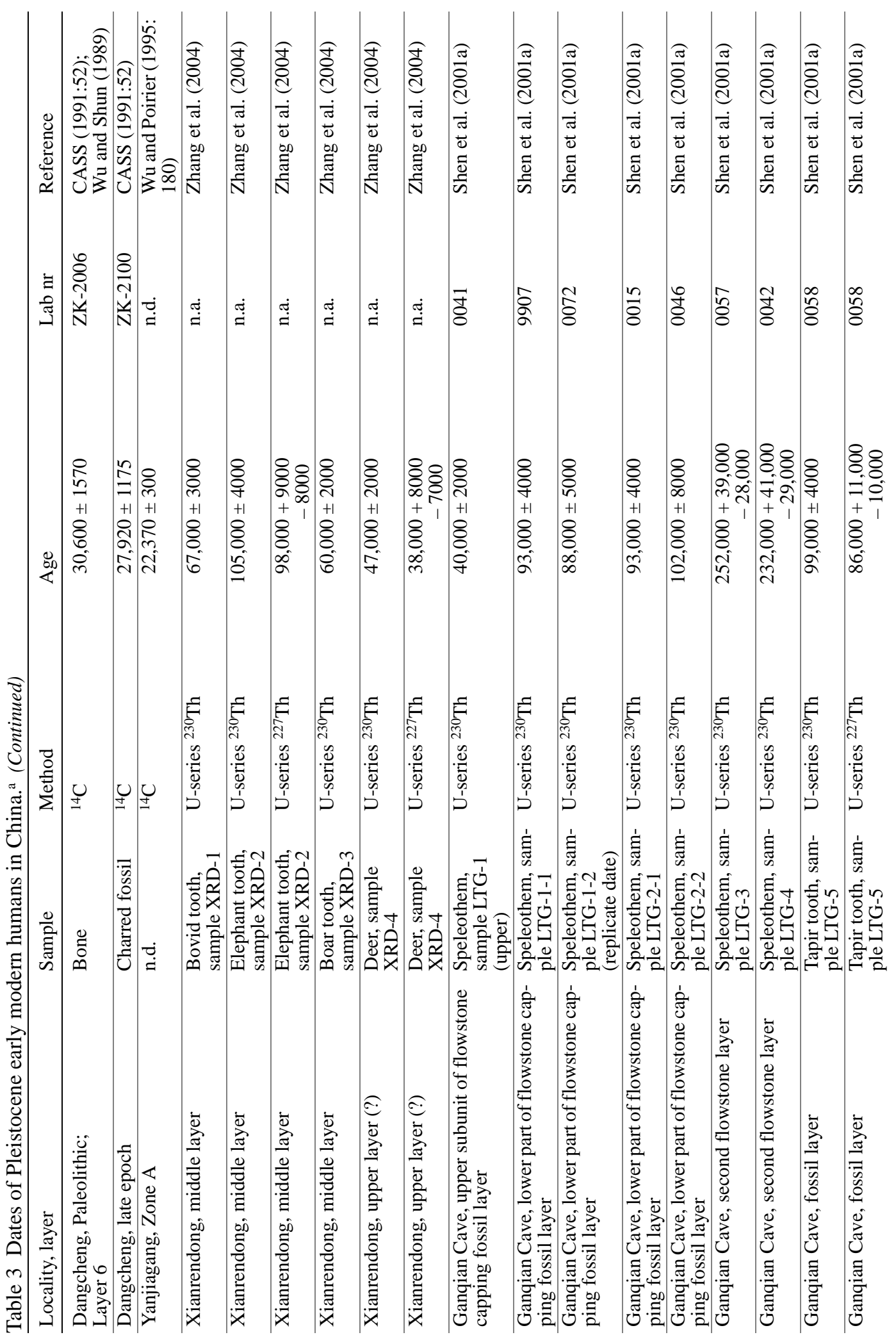




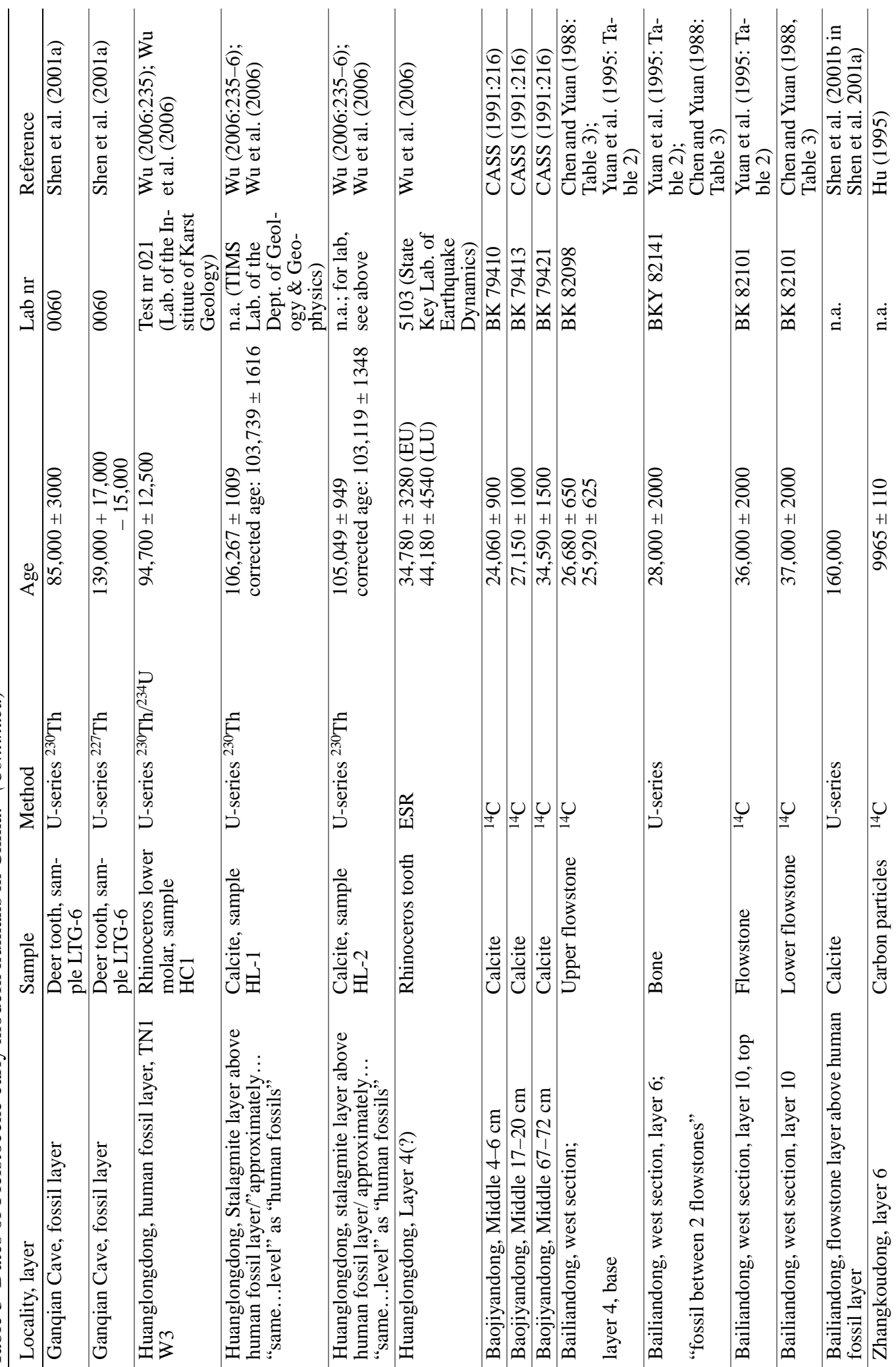




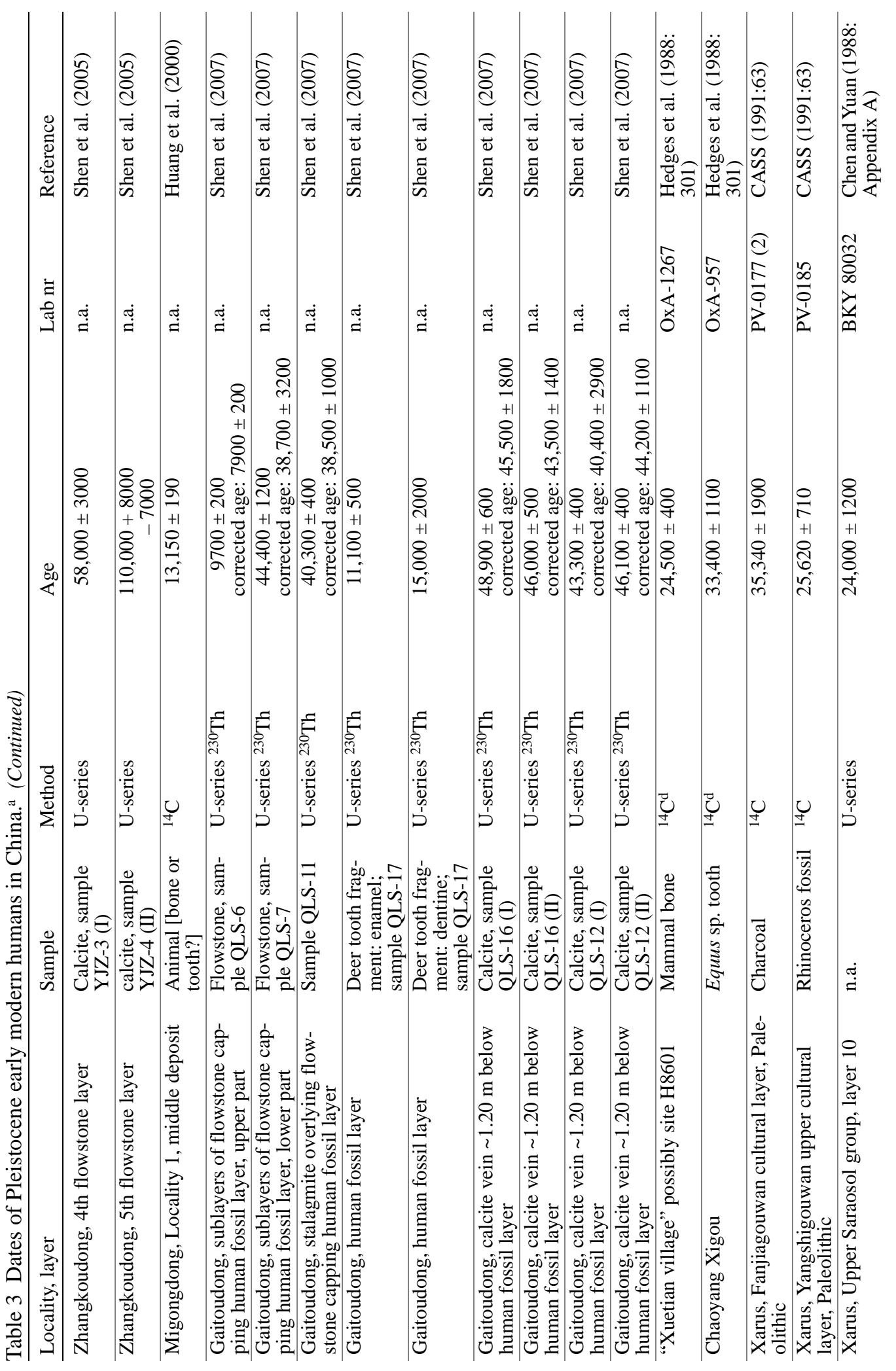




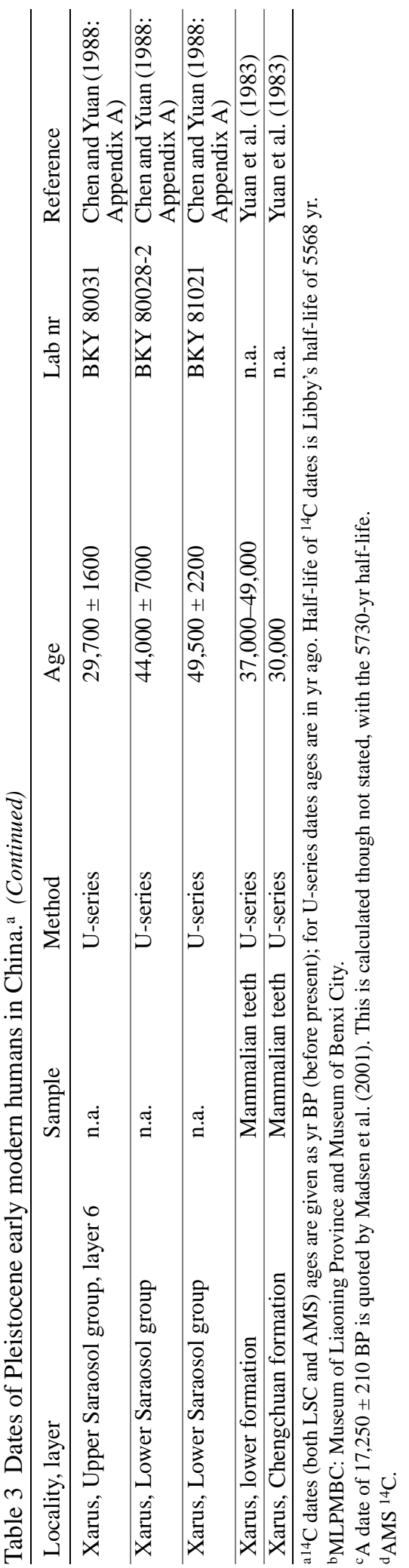




\section{Shiyu}

An as yet unstudied human occipital fragment from Shiyu (locality 63661), Shuoxian County, north Shanxi Province, was discovered in layer 2 of this open-air site in 1963 (Chia et al. 1972; Figure 1). Non-human fossils, lithic artifacts ( 15,000), burnt fossils, and an up to 0.25 -m-thick ash layer were also found in layer 2 (0.9-1.5-m-thick fluvial sands and gravel). The non-human fossils (in a fragmentary state of preservation and mainly teeth) comprise about 12/15 species (including Crocuta sp. and Coelodonta antiquitatis), thought to predate Shandingdong (Chia et al. 1972; Wu and Wang 1985; and see Wu and Poirier 1995:177). The ${ }^{14} \mathrm{C}$ date is $~ 28,000$ BP (CASS 1991:41; Table 3). The exact provenance of the occipital fragment within layer 2 is unclear (see e.g. Chia et al. 1972).

\section{Tongtianyan (Liujiang)}

In terms of depositional context and age, the $H$. sapiens from the Tongtianyan Cave in Liujiang County, north-central Guangxi Zhuang Autonomous Region, is one of the most debated fossil human specimens in paleoanthropology (Figure 1). After the discovery of a human cranium, partial axial skeleton (14 whole bones and fragments), most of a right innominate, and 2 femoral shafts during guano digging of the cave deposits by farmers in 1958, a geological study by Li Youheng (in Woo 1959; Wu and Poirier 1995:186-93) concluded that the human remains derived from the upper deposit of unconsolidated limestone breccia. By the time of the discovery of human fossils, guano diggers had emptied most of the cave's deposits. A giant panda skeleton was found near the human remains. Both the human and panda fossils were covered with "reddish matrix" and considered to be of Late Pleistocene age (Woo 1959:109). More mammalian fossils were recovered from consolidated yellow sediment, and these were judged to be of Middle Pleistocene origin (Woo 1959). The morphological features of Tongtianyan were considered to identify the earliest modern $\mathrm{H}$. sapiens in China (Woo 1959).

${ }^{14} \mathrm{C}$ dating of layer 2 gave an age of more than 40,000 BP (CASS 1991:219). U-series dating of cave sediments resulted in an age of $\sim 67,000 \mathrm{yr}$ for the human materials (Yuan et al. 1986; Table 3), but it is unclear how the dated sample relates to these fossils (Chen and Zhang 1991). The most recent effort at dating the human fossils also refers to calcrete matrix remaining on and in various parts of the human partial skeleton that points to a provenance in the intrusive breccia or "refilling breccia" according to Shen et al. (2002a). The Upper and Lower Units of the cave contain no carbonate. The most recent dating assumes the "probable" provenance of the hominid in the intrusive breccia (Shen et al. 2002a: Figure 3). Samples of flowstone for U-series dating of the hominid were taken from several locations and different sediments within the cave (for a full list of dates, see Shen et al. 2002a: Tables 1-3). One of these (sample LJR-17) is at the approximate same level as the assumed human fossil level in the intrusive breccia (Shen et al. 2002a: Figure 3; Table 1) with a mean age of $\sim 111,000$ yr. Dates from the second flowstone (FL2) located in the Upper Unit (sample LJR-2) provide a minimum age for the intrusive breccia below of $\sim 68,000 \mathrm{yr}$. An average date of $\sim 153,000 \mathrm{yr}$ for FL3 from the Middle Unit (sample LJR-6) is suggested to be the earliest age of the "washout event" of the intrusive breccia, while an average date of $139,000 \mathrm{yr}$ (sample LJR-8), is the earliest age for the intrusive breccia, with a "best age estimate" of 111,000-139,000 yr for the breccia and human fossils; the absence of stratification in the breccia would indicate a rapid deposition event (Shen et al. 2002a:824). The authors also note that the human fossils may derive from the Middle Unit, a "carbonate-cemented clay," thus dating them to more than 153,000 yr based on the FL3 flowstone layer (sample LJR-6; Shen et al. 2002a:825). This flowstone lies above the FL4 flowstone layer with uncorrected dates of $\sim 250,000$ and 228,000 yr (sample LJR-31; see Shen et al. 2002a: Figure 3), which would make the fossils even older. 


\section{Huangshanxi (Ziyang)}

A modern $H$. sapiens cranium, a mostly edentulous hard palate and partial maxilla (lacking the basicranium, and parts of other bones, including most facial bones), was found during railway bridge construction on the right bank of the Huangshanxi River in Ziyang County, central Sichuan Province, in 1951 (e.g. Pei 1957a; Woo and Wu 1957; Wu and Zhang 1985; Figure 1). In the same year as the discovery, 2 tests pits (east and west sites) were excavated east and west of the railway bridge foundation in the area where the human fossils were found. The northwest area of the east site is closest to the presumed human fossil place (Pei 1957a; Figure 1). The human bones have long been assumed to derive from layer 3 (1.0-1.5-m-thick sands with small pebbles) where a small number of fragmentary fossils and many fossilized roots, branches, and leaves were also found; no fossils or artifacts were found in layers 1 and 4 (6.0 m mean thickness: yellow-red clay and gravel layer, respectively). Some fossil wood was recovered from layer 2 (1-m-thick gray clay intercalated with sands; Pei 1957a: Figure 2; and see Wu and Poirier 1995:199). The non-human fossils include about 13 species of a southern mammalian fauna (Pei 1957b) of which some of the younger (H. sapiens) group is less fossilized than the earlier group (Pei 1957a). A bone awl, dark brown in color similar to the human bones, was found during excavation near the base of layer 3 (Pei 1957c). A Late Pleistocene age was first assumed on account of several extinct taxa in the fauna (e.g. Pei 1957b; and see Wu and Wang 1985). However, the depositional/stratigraphic provenance of the human fossils remains uncertain (e.g. Aigner 1981:67; Wu and Zhang 1985; Etler 1996).

Fluorine analysis of 6 fossil samples from Huangshanxi by Chiu (1955), initiated by Pei Wenzhong, identified the human cranium as "slightly fossilised" with a $0.79 \%$ fluorine content, while the most fossilized specimen (an indeterminate animal fossil), contained 1.32\% fluorine. The $\mathrm{H}$. sapiens would therefore be younger than the more fossilized mammalian bones (Chiu 1955; Pei 1957a; and see $\mathrm{Wu}$ and Poirier 1995:199). ${ }^{14} \mathrm{C}$ dates on wood assumed to derive from an equivalent stratigraphic context as the human cranium date to the Early Holocene (e.g. CASS 1991:222-3; Table 3).

Subsequent surveys and test excavations of the site's environs found many tree fossils, pollen, and few mammalian fossils in a gray clay layer, a lacustrine deposit (The Quaternary Section of the Chengtu Institute of Geology 1974). This layer is situated below a yellow-red clay (upper stratum), a fluvial deposit, and above a gravel layer (lower stratum), a riverbed deposit. Because of the similarity of tree fossils and pollen to those extant in the area and the mostly extant mammalian fossils, it is argued that they derive from the Early Holocene period, as indicated by ${ }^{14} \mathrm{C}$ dates. The condition of the gray clay layer mammalian fossils indicates river flood transportation to the area in contrast to the short distance transportation of the human cranium (The Quaternary Section of the Chengtu Institute of Geology 1974).

Another excavation of Ziyang [Huangshanxi] Man Locality B in 1981, 100 m west of the human fossil site, yielded 6 mammalian fossils (including Cervus sp., Rhinoceros sinensis), tree fossils, and 172 lithic artifacts from layer 6 (pebble layer, of a total of 7 recognized layers), $~ 8 \mathrm{~m}$ below the surface. The similarity of faunal taxa, and comparable color and degree of fossilization of the modern humans and the Site B fossils indicates that the localities are elements of the same fauna ( $\mathrm{Li}$ and Zhang 1984). A ${ }^{14} \mathrm{C}$ date of $\sim 37,000 \mathrm{BP}$ (Li and Zhang 1984; Wu and Poirier 1995:199) is from a sample above layer 6 at Locality B ( $\mathrm{Li}$ and Zhang 1984). A similar date is from a sample below layer 6 (Wang 1989: Table 4.1) at $11 \mathrm{~m}$ below the surface (CASS 1991:223; Table 3), thus below the presumed depth of the human fossils. 


\section{Miaohoushan Dongdong}

There are 2 sites at Miaohoushan, both of them limestone caves: the Middle and Late Pleistocene Miaohoushan site (also called Cave A) and the Late Pleistocene Miaohoushan Dongdong site (East Cave, also called Cave B). These sites are located on the Liaodong Peninsula in Benxi County, central Liaoning Province (Figure 1) and were discovered in 1978 and excavated from 1978 to 1980. Both sites have yielded animal, human, and plant fossils, and evidence of human activity. Archaic and modern $\mathrm{H}$. sapiens fossils were found at Miaohoushan and modern $\mathrm{H}$. sapiens at Miaohoushan Dongdong (Museum of Liaoning Province and Museum of Benxi City 1986:98-9).

Miaohoushan Dongdong is situated on the southern inclination of the Miaohoushan hill. The cave contains 5 layers (total thickness of 6.7-10.2 m). Of the 2 fossiliferous layers, layer 2 (0.4-0.6-mthick clay with breccia) yielded the modern human fossils ( 2 fragments: parietal bone 1 and parietal [or temporal] bone 2). These were found at the base of layer 2 and associated with 5 mammalian species (including C. ultima, Cervus sp.) and a quartzite artifact. A human radius from the highest part of layer 2, $0.8 \mathrm{~m}$ above the human cranial bones, was associated with Cervus sp. and Sus scrofa. The fossils of the overlying layer 3 (0.8-2-m-thick breccia and gravel with some sandy clay) were found in the bottom part, including S. scrofa (Museum of Liaoning Province and Museum of Benxi City 1986:98-100, 6; see also Wu and Poirier 1995:181). According to the primary source, S. scrofa was not present within layer 2 (Museum of Liaoning Province and Museum of Benxi City 1986:99). The stratigraphic section of Miaohoushan Dongdong, however, shows a thin, unnumbered layer between layers 3 and 2 from which the radius derives and with no associated animal fossils, while the fossils of layer 3 are illustrated in the lower and not the basal part of this layer (Museum of Liaoning Province and Museum of Benxi City 1986: Figure 5.1).

The radius is stratigraphically above the cranial bones and less fossilized and therefore considered to be younger than the other human bones (Museum of Liaoning Province and Museum of Benxi City 1986:6). A ${ }^{14} \mathrm{C}$ date places layer 2 at $~ 28,000 \mathrm{BP}$; however, this date is also referred to layer 3 (Museum of Liaoning Province and Museum of Benxi City 1986:100, 91, 8; Table 3). In CASS (1991:78), the origin of the ${ }^{14} \mathrm{C}$ sample is described as "Xi Dong," i.e. West Cave and at $0.5 \mathrm{~m}$ lower, perhaps a misprint (Table 3 ).

\section{Yuanyang (Wushan)}

Discovered during a survey in 1984, the open-air site of Yuanyang, near Yuanyang town in Wushan County, south Gansu Province, is one of the earliest dated modern humans (Figure 1). Several parts of a H. sapiens cranium were found (frontal bone, both parietals, and nasal and sphenoid fragments) in the central part of a calcified clay layer with some gravel of $15 \mathrm{~m}$ thickness. This layer is capped by 2 "layers" reaching a depth of about 23-25 m (Xie et al. 1987 in Wu and Poirier 1995:182-3). A ${ }^{14} \mathrm{C}$ date of $\sim 38,000 \mathrm{BP}$ on clay from the fossil layer is mentioned by Wu and Poirier (1995:182-3) as dated by the Laboratory of Geography of Lanzhou University, but no further information is given (Table 3).

\section{Laishui}

Laishui, in Laishui County, central Hebei Province, is an open-air site discovered and excavated in 1987 (now destroyed due to house construction; Figure 1). A partial modern H. sapiens skeleton, including a skull, was found associated with animal fossils and lithic artifacts at the base of Malan Loess. A U-series date of this unstudied skeleton of about 28,000 yr was obtained on an associated animal fossil (Lü Zun'e, personal communication, 1994; Keates 2003; and see Etler 1996) and a 60,000 yr date has also been reported (Wolpoff 1999:728), but no further details are available. 


\section{Xiaohuidong (Shuicheng)}

Xiaohuidong, Shuicheng County, west Guizhou Province, was discovered as a result of road construction in 1973 with much of the site no longer extant (Figure 1). Excavations in 1973 and 1974 revealed 3 stratigraphic layers in this cave (Cao 1978). Layer I (0.1-0.3-m-thick flowstone) overlies layer II ( 0.05-0.15-m-thick ash with calcium carbonate) where burnt bones and stones and carbon particles were found. Fossils, including a modern human left upper canine, and 56 lithic artifacts derive from layer III ( 0.05-0.45-m-thick sandy clay and breccia) (Cao 1978; see also Wu and Poirier 1995:221) close to and lower than the other fossils (Cao 1978). Five mammalian species were identified (including Stegodon sp., Sus sp.). The U-series date of layer 3 is $~ 52,000$ yr (see Yuan et al. 1986; Table 3); an age range of 55,000-49,000 yr has also been suggested (Chen and Yuan 1988: Table 6). More recently, U-series dates of layer 1 and the lower part of layer 3 date the archaeological specimens to $\sim 110,000-230,000 \mathrm{yr}$ (Shen 1993:277, Table 1), although there are also other dates for layer 1 of $\sim 59,000 \mathrm{yr}$ and $\sim 356,000 \mathrm{yr}$ (Table 3).

\section{Longtanshan Site 1}

Prior to the discovery of 2 human fossils in 1977 at Longtanshan Site 1, Chengong County, west central Yunnan Province, quarry workers had unearthed mammalian fossils and lithic artifacts from 1973 to 1977 (Figure 1). Longtanshan Site 1 is a fissure site with 2 identified layers: a 2-m-deep red loam layer (cemented to a small degree) and a 1.3-m-thick sandy clay layer with thin travertine plates at the top and basal parts. The modern human fossils (right $\mathrm{PM}_{1}$ and left $\mathrm{M}_{1}$ ) are thought to originate from the sandy clay layer based on the extent of fossilization, color, and adhering deposit. Most of the fauna is from the sandy clay layer; a small number of fossils is from the base of the red loam layer. The site was dated on the basis of the fauna that comprises 12 species (e.g. C. ultima, $R$. sinensis) to the Late Pleistocene (Zhang et al. 1978 in Wu and Poirier 1995:230). The ${ }^{14} \mathrm{C}$ date is 18,000 BP (CASS 1991:240; Table 3).

\section{Shuidonggou}

Shuidonggou, Lingwu County, northern Ningxia Hui Autonomous Region, is an open-air site complex long known for its rich fossil fauna and lithic artifact assemblages and also for burnt bones (Figure 1). Discovery and excavation in 1923 (e.g. Teilhard de Chardin and Licent 1924), was followed by further investigations (e.g. Chia et al. 1964), the most recent ones in the 1990s, establishing Shuidonggou as the oldest of the Initial Upper Paleolithic sites in China (e.g. Brantingham et al. 2001; Madsen et al. 2001; Barton et al. 2007). The 2 main sites at Shuidonggou, namely Locality 1 and Locality 2, located about $100 \mathrm{~m}$ distance from each other, are comparable in terms of stratigraphy (Gao et al. 2002) though Locality 1 has several more layers (see Gao et al. 2002: Figure 2).

In 2000, a modern $H$. sapiens cranial bone (posterior part of the right parietal) was discovered at Shuidonggou, Locality 1 (see Wu et al. 2004). The human specimen, with "moderate fossilisation" was found at the base of stratum 7, close to the top of stratum 8, "just above the erosion surface of the upper part of the late Pleistocene stratum" (Wu et al. 2004:84). There are a total of 8 strata, with strata 1-7 of Holocene age and stratum 8 of Late Pleistocene age. This stratigraphy follows that of the Geological Survey of Ningxia Museum and Ningxia Geological Bureau (1987, in Wu et al. 2004). Stratum 8 contains Late Pleistocene fauna and Upper Paleolithic artifacts, and, according to Wu et al. (2004:84), the parietal can probably be associated with stratum 8 . Of the $4{ }^{14} \mathrm{C}$ dates, the one nearest to the suggested provenance of the human bone is a date for the upper part of stratum 8 at 16,000 BP. Strata below this have older ${ }^{14} \mathrm{C}$ and U-series dates (Wu et al. 2004: Figure 2; CASS 1991:293; Chen et al. 1984; Table 3). 


\section{Lianhuadong}

Excavation of the cave site of Lianhuadong, Zhenjiang County, southwest Jiangsu Province (Figure 1), in 1981, recovered a modern $H$. sapiens fossil (most likely $\mathrm{M}_{2}$, rootless) associated with other mammalian fossils (15 species, including Dicerorhinus sp., S. scrofa) from layer 2 or layer 3 (loam with limestone blocks of $1.0 \mathrm{~m}$ and $1.5 \mathrm{~m}$ thickness, respectively); fewer fossils were found in layer 2 (see Li et al. 1982). Four layers were recognized including layer 1 (0.2-m-thick surface deposit) and layer 4 (sandy loam, unknown depth). The age of the fossils is considered to be Late Pleistocene (Li et al. 1982; see also Wu and Poirier 1995:221-2). U-series dates of animal teeth from layer 2 would indicate an age range of 104,000-136,000 yr for the human tooth (Pan et al. 2002; Table 3).

\section{Wuquidong (Jiande)}

The cave site of Wuquidong was discovered in 1974 in Jiande County, west Zhejiang Province (Figure 1). Mammalian fossils (11 species, including $R$. sinensis, Muntiacus sp.) and a human right upper canine were found in the upper layer ( 0.35-m-thick purple clay), considered to be later Late Pleistocene. Mammalian fossils also derive from the lower layer ( 1.10-m-thick yellow-red clay) interpreted as early Late Pleistocene (Han and Zhang 1978; Wu and Poirier 1995:228-9). U-series dates of the upper layer bracket the age of the human tooth between $~ 97,000$ and 108,000 yr (Yuan et al. 1986; Table 3). In a subsequent publication, the U-series dates of the upper layer range from $\sim 90,000-117,000 \mathrm{yr}$, but it is unclear what the 117,000 yr date is based on (see Chen and Yuan 1988: Table 6 and Appendix A).

\section{Nanshandong}

Mammalian fossils discovered by workers at Nanshandong in Fusui County, south Guangxi Zhuang Autonomous Region (Figure 1), in 2000, include 2 well-preserved modern $H$. sapiens teeth (left $\mathrm{M}_{3}$ and right $\mathrm{M}_{2}$ ). These were found in a $\sim 2$-m-thick fine sandy clay layer below calcite of this cave. The animal fossils comprise 9 species (including $R$. sinensis, Equus hemionus). U-series dating returned dates of $\sim 51,000$ and 53,000 yr (Table 3) with a "corrected" 1- and 2- $\sigma$ age range of 33,000-44,000 yr (Wang and Mo 2004: Table 4) or 30,000-40,000 yr (Wang and Mo 2004:135).

\section{Dangcheng (Heshun)}

The cave site of Dangcheng locality 83001 in Heshun County, east Shanxi Province, is one of several cave sites near Dangcheng village (Figure 1). It was excavated in 3 field seasons (1983-85) and yielded 24 mammalian species, including modern $H$. sapiens ( 2 cranial fragments, unspecified), and $3000+$ lithic artifacts from layer 4 (0.60-m-thick sand). Eight layers were identified (layers 8-1, top to bottom), and non-human fossils and artifacts were also found in layer 6 . The fauna (including $C$. ultima, Gazella przewalskyi) is Late Pleistocene. The ${ }^{14} \mathrm{C}$ date for layer 6 (Wu and Shun 1989) is $\sim 30,000$ BP. Another ${ }^{14} \mathrm{C}$ date is $\sim 27,000$ BP (CASS 1991:52; Table 3).

\section{Yanjiagang}

A heavily weathered posterior fragment of a human right parietal was discovered on the surface of Yanjiagang farm in an eroded sandy part on the eastern side of a site (Zone A) under excavation near Harbin in southwest Heilongjiang Province in 1982 (Figure 1). Excavations were conducted from 1982-85. Four layers were identified in Zone A. Most mammalian fossils were found in the lower part of "layer 2" (loess) and the upper part of "layer 4" (fine sands), the former younger than the latter (Wu and Poirier 1995:180). The main fossil and cultural layer is $3.5 \mathrm{~m}$ below the ground surface and $0.8 \mathrm{~m}$ thick. Loess, black earth, and "cultivated soil" are situated above this layer (You et al. 
1986:99). The Zone A “upper fossil bed" ("layer 2") fauna comprises 11 species (including Mammuthus primigenius, G. przewalskyi). Nine lithic artifacts were also found. A ${ }^{14} \mathrm{C}$ date of $\sim 22,000 \mathrm{BP}$ was published by the Management Committee of Cultural Relics of Heilongjiang Province et al. in 1987 (see Wu and Poirier 1995:180; not included in CASS 1991; Table 3), but it is unknown to this author if the report contains information on the stratigraphic position of the dated sample. Similarly, the stratigraphic provenance of $5{ }^{14} \mathrm{C}$ dates from Yanjiagang (from $~ 26,560$ to $>41,300 \mathrm{BP}$ ) is not clear (see Ives et al. 1994).

\section{Xianrendong (Xichou)}

The cave site Xianrendong ("Xuanrendong” in Chen and Qi 1978) in Xichou County, southwest Yunnan Province, was first excavated in 1965 and 1970 with the discovery of mammalian fossils (Figure 1). More fossils, including 3 modern human teeth and 2 modern human teeth, were recovered in 1972 and 1973, respectively, the latter from a disturbed depositional context (Chen and Qi 1978). Three layers were identified: an upper layer (0.3-0.5-m-thick limestone) with mammalian fossils; a middle layer (0.8-m-thick hardened sand and clay) with mammalian fossils, including the human teeth; and a lower layer (1.3-m-thick clay) (Chen and Qi 1978). The 5 human teeth are 2 right lower canines, a right $\mathrm{M}_{1}$ or $\mathrm{M}_{2}$, a right $\mathrm{PM}_{1}$, and a right $\mathrm{DM}_{2}$ (Chen and Qi 1978; and see IVPP 1980:152).

The non-human fossils (32 species, including Stegodon orientalis, Megatapirus augustus) are representative of a Late Pleistocene fauna (Chen and Qi 1978; see also Wu and Poirier 1995:223). Useries dates of 3 animal teeth with "adhered matrix" are argued to derive from the middle layer range from $\sim 67,000-105,000$ yr. One tooth, which is perhaps from the upper layer, dates to $\sim 38,000$ $47,000 \mathrm{yr}$. The range of $47,000-105,000 \mathrm{yr}$ is considered to date the human fossils, although Zhang et al. (2004) suggest that these may be considerably younger than the true age because speleothem calcites are deemed to be more reliable for U-series dating (Table 3).

\section{Ganqian (Tubo)}

Excavations in 1981 at Ganqian Cave (locality 81001; “Ganjian Cave” in Li et al. 1984), Tubo district, Liujiang County, north-central Guangxi Zhuang Autonomous Region (Figure 1), recovered 5 modern $H$. sapiens teeth with 18 species of fragmentary mammalian fossils (including Hystrix subcristata, Ailuropoda melanoleuca baconi) in a clay layer near the base of the cave, $\sim 10 \mathrm{~m}$ below the ground surface. Four human teeth are from a drug store and found by collectors in Ganqian Cave (Li et al. 1984; Wu and Poirier 1995:210). Eight human teeth were found in 1997 by local collectors in the Inner Hall of the cave in layer 2 (1.1-m-thick clayey sediment) associated with a large number of mammalian fossils (Wang et al. 1999). The human teeth from the excavations in 1981 (unerrupted left $\mathrm{I}^{1}$, left $\mathrm{M}^{1}$, 3 right $\mathrm{M}^{1}$, right(?) $\mathrm{M}^{2}$, left $\mathrm{M}^{3}$, right lower $\mathrm{M}$, and left $\mathrm{DM}_{2}$ : Li et al. 1984; Wu and Poirier 1995:210-2) and collections in 1997 (right $\mathbf{M}^{1}, 2$ left $\mathrm{M}^{1}$, "probably" left $\mathrm{M}^{1}$, "probably" right $\mathrm{M}^{2}$, "probably" right $\mathrm{M}_{2}$, "likely" left $\mathrm{M}^{3}$ or "possibly a second molar," left $\mathrm{M}^{3}$ : Shen et al. 2002b:81-2; and see Wang et al. 1999) vary in their degree of fossilization (Shen et al. 2002b).

The Ailuropoda-Stegodon fauna indicates a late Late Pleistocene age (Li et al. 1984). More recently, U-series dates of the flowstone above and below the fossil layer give an age estimate for the human teeth of $\sim 94,000-220,000$ yr. U-series dates of animal teeth from the fossil layer are $~ 99,000$ and $\sim 86,000 \mathrm{yr}$ (Table 3). According to Shen et al. (2001a, 2002b), these would also favor an age estimate of more than $100,000 \mathrm{yr}$ for the human fossils. 


\section{Huanglongdong [Hubei Province]}

Discovered during a survey in 2004, the cave site of Huanglongdong, Yunxi County, north Hubei Province (Figure 1), was excavated in 2004, 2005, and 2006; all specimens were plotted (see Wu 2006:18-9). In 2004-2005, 5 modern $H$. sapiens teeth (upper canine, left $\mathrm{M}^{3}$ (peglike), right $\mathrm{I}_{2}$, left $\mathrm{M}_{3}$, and right $\mathrm{M}_{2}$ ) were recovered associated with mammalian fossils (including burnt specimens) and artifacts. In 2006, animal fossils, including 2 modern human teeth ( $\mathrm{I}^{1}$ and $\left.\mathrm{I}_{2}\right)$, freshwater crab, snail, fish, 40 mammalian species (including H. subcristata, S. orientalis), 11 lithic and 6 bone artifacts were found (Wu 2006); 22 lithic artifacts are also mentioned (Wu et al. 2006). Some animal bones are cut-marked (Wu et al. 2006) and charcoal ( 62-73\% carbon content) was identified in the human fossil layer (Liu et al. 2008). The archaeological specimens are from layer 3 (0.58-1.01 m thick red-brown silt clay) (Wu 2006:11; Wu et al. 2006), or 0.48-1.0 m thick (Wu et al. 2007). The human fossils and artefacts are from the base of layer 3 and most of the fauna is from this layer (Wu et al. 2006). There are a total of 5 layers with a depth of $1.20-4.22 \mathrm{~m}$ (Wu et al. 2006). The nonhuman fossils are a Late Pleistocene fauna (Wu 2006:11; Wu et al. 2007). U-series dating places the hominid layer at $\sim 94,000 \mathrm{yr}$ and the overlying stalagmite layer at $100,000 \mathrm{yr}$ (Wu 2006:235-6; Table 3). According to Wu et al. (2006:2494, 2497), the human fossils were discovered "in association with the stalagmites" or "at approximately the same horizontal level" as "the human fossils...", of which the latter statement accords with the position of the specimens as shown in their Figure 2; the stalagmite level is shown to be located about $0.80 \mathrm{~m}$ away from the fossils. The single ESR date is $34,000-44,000 \mathrm{yr}$ (Table 3), and Wu et al. (2006:2497) argue for a likely date of $\sim 100,000 \mathrm{yr}$ for the human fossils dismissing the ESR sample because of possible "complicated absorption and leaching" in the burial environment in contrast to the "pure and dense" U-series samples from "a closed environment.”

\section{Baojiyandong}

After the discovery of mammalian fossils, including a human tooth (right $\mathrm{M}_{2}$ ), by students at Baojiyandong, a cave in Quilin City, northeast Guangxi Zhuang Autonomous Region, in 1979, a survey of this site in 1980 recovered a second human tooth (left $\mathbf{M}_{3}$ ), mammalian fossils, and 12 lithic artifacts (Wang et al. 1982; Figure 1). The major part of this cave had previously been exploited by fertilizer digging. Three layers were recognized in the main chamber (layers I-III, depth of 1.00-1.95 m; layer 1, 0.10-0.25 m thick; layer III, $0.70 \mathrm{~m}$ thick). The fossils are from layer II (0.20-1.00-m-thick gray-yellow sediment). A Late Pleistocene age estimate is based on the fauna (including M. augustus, R. sinensis; Wang et al. 1982; see also Wu and Poirier 1995:217-8). Of the $3{ }^{14} \mathrm{C}$ dates, the oldest at $\sim 34,000$ BP is at the depth of layer II (i.e. $0.30-1.25 \mathrm{~m}$; CASS 1991:216; Table 3).

\section{Bailiandong}

Discovered in 1956, excavations of Bailiandong, Liuzhou County, Guangxi Zhuang Autonomous Region, recovered fragmentary mammalian fossils, including 2 human teeth (right molar and left M3) and lithic artifacts, from layer 7 (yellow-brown clay) of the west section of this cave (Zhou 1994a; Figure 1). Lithic artifacts were also found in layer 4 (shallow yellow-brown clay with a calcareous concretion in the upper part) and layer 5 (red-brown clay, with shell). Ten stratigraphic layers have been identified in the west section, with layers 4-7 of Late Pleistocene age, containing some extinct species of the Ailuropoda-Stegodon fauna (Zhou 1994a,b). A ${ }^{14} \mathrm{C}$ date for layer 4 is 26,000 BP (Chen and Yuan 1988; Yuan et al. 1995). Closer to the human fossil layer, a U-series date for layer 6 is $\sim 28,000 \mathrm{yr}$ (Yuan et al. 1995). A U-series date of flowstone above the human fossil layer is $\sim 160,000 \mathrm{yr}$, the minimum age for the human fossils (Shen et al. 2001b; Table 3). 


\section{Zhangkoudong}

The discovery of Zhangkoudong in 1989, a cave site in Yiliang County, Yunnan Province, led to excavation of the deposits in 1990 by Hu (1995; Figure 1). Eighteen layers, including 9 flowstone layers, were identified and divided into an upper and a lower group. Modern human fossils (40 teeth, unspecified), lithic and bone artifacts, and carbon particles were found in layer 4, belonging to the upper group. This layer reaches a thickness of $1.26 \mathrm{~m}$, and lies $0.36 \mathrm{~m}$ below the surface (Hu 1995). However, Shen et al. (2005:359) note, “...because of incomplete excavation notes, the temporal position of the hominid teeth remains unresolved.”

${ }^{14} \mathrm{C}$ dating of carbon particles from layer 6, i.e. 2 layers below the hominid bearing layer, date to $\sim 9000$ BP (Hu 1995; Table 3). The ${ }^{14} \mathrm{C}$ date for layer 14 is 14,550 $\pm 450 \mathrm{BP}$ (Hu 1995). Shen et al. (1995:358) question "the reliability of conventional ${ }^{14} \mathrm{C}$ dating of fossil bones...," stating "the carbonate fraction of bones is unsuitable to [sic] dating." (and see Shen et al. 2007:2113 and their reference to Taylor 1992). U-series dates of calcite from the 4th and 5th flowstone layers that lie directly above and below layer 6, respectively, are $~ 58,000$ and 110,000 yr (Shen et al. 2005; Table 3).

\section{Migongdong, Locality 4}

Migongdong site, in Wushan County, east Sichuan Province, was found in 1999 and consists of 5 cave localities (Figure 1). The deposits contain an upper part (0.2-m-thick breccia), a middle part ( 1.5 -m-thick clay and sandy clay), and a lower part (mostly gravel and sands). Three layers were identified at Locality 4 in the middle part of the deposit, from top to bottom: layer 3 ( $0.1 \mathrm{~m}$ thick), layer 2 (1.2 $\mathrm{m}$ thick), and layer 1 ( $3 \mathrm{~m}$ thick). However, the total thickness of the middle deposit of Locality 4 is $4.3 \mathrm{~m}$, more than the $\sim 1.5 \mathrm{~m}$ stated for the Migongdong deposits. Modern human fossils (2 mostly complete parietals) were found in layer 1. Animal fossils (4 species, including Apodemus sp., Cervus elaphus) and lithic artifacts were found lower in layer 1 than the human bones (see Huang et al. 2000: Figure 5). ${ }^{14} \mathrm{C}$ dates the middle deposit of Locality 1 to $13,000 \mathrm{BP}$ (Huang et al. 2000; Table 3).

\section{Gaitoudong (Laibin)}

Three modern H. sapiens fossils, described as a "skull base" (Wu and Poirier 1995:193), mammalian fossils, shells of extant mollusks, stone artifacts, and evidence of fire, were found in 1956 in the Outer Corridor of a cave on Qilinshan (Qilin hill) in Laibin County, central Guangxi Zhuang Autonomous Region (Figure 1). Fertilizer digging had removed some parts of the deposits (Chia and Woo 1959). The 2 identified layers in Gaitoudong are a yellowish-gray breccia interbedded with 3 sublayers of stalagmitic crust and referred to as the upper layer. A red loam below it is called the lower layer. The first sublayer yielded the human fossils, Cervus sp. and Sus sp. tooth fragments, and 3 lithic artifacts. Mammalian fossils were also found below the human fossil layer. A thin ash layer, including burnt bone and charcoal, is from the upper layer (Chia and Woo 1959). The human fossils (an almost complete hard palate with about 6 teeth and the connecting lower portion of the maxilla, much of the right zygomatic with part of the orbit, and an occipital fragment) are still partly encased in matrix (possibly breccia; see Wu and Poirier 1995: Figure 4.8).

The fossils are considered to be Late Pleistocene (Chia and Woo 1959; Wu and Poirier 1995:1934). Several U-series dates have been generated recently for Gaitoudong. According to Shen et al. (2007:2113, 2112), because "the hominid specimen was recovered from the deposits in-between, its age can be securely bracketed between 39,000-44,000 yr," with "a weighted mean" for the human fossil of 44,000 yr. However, the respective samples (QLS-12 and QLS-16) are shown as deriving 
from calcite veins about $0.45 \mathrm{~m}$ and $0.60 \mathrm{~m}$ below the human fossil (see Shen et al. 2007: Figure 3). A deer tooth fragment from the human fossil layer is U-series dated to 11,000 and 15,000 yr, whereas the flowstone capping the human fossil layer is U-series dated to 44,000 (sample QLS-7) and $\sim 9000 \mathrm{yr}$ (sample QLS-6). The date for the flowstone is considered to be more reliable, because "fossil bones are susceptible to post depositional U migration, leading generally to underestimated dates in a cave setting" (Shen et al. 2007:2113). The Holocene date for the QLS-6 flowstone sample could be due to "recent speleothem formation" (Shen et al. 2007:2112). The origin of another Useries date (sample QLS-11) is a stalagmite positioned on the flowstone layer (Shen et al. 2007: 2111; Figure 3), but also referred to as deriving from the capping flowstone (Shen et al. 2007:2112; Table 3).

\section{Site H8601 (Xuetian)}

Mammalian fossils and lithic artifacts were excavated from the base of an irrigation channel that had experienced water erosion in 1986. Site H8601 is located near the village of Xuetian, Wuchang County, south Heilongjiang Province (Figure 1). (In the proximity, non-human fossils were recovered from Site H8602. This appears to be the site mentioned by Ives et al. [1994] where animal fossils found $8 \mathrm{~m}$ below the surface have been ${ }^{14} \mathrm{C}$ dated to $\sim 38,000-40,000$ BP.) Fossils and 3 lithic and several (possible) bone artifacts were found in layer 2 (a 3.5-m-thick silt) at $2.6 \mathrm{~m}$ below the surface (layers 5-1 from top to bottom). The modern human fossils are a left parietal fragment (lower part, in 3 pieces) and a left tibia fragment. The 6 mammalian species (including M. primigenius, $C$. antiquitatis) indicate a Late Pleistocene age (Yu 1988; and see Wu and Poirier 1995:179). There is a ${ }^{14} \mathrm{C}$ date from "Xuetian village" deposits in the same county and province as Site H8601, but no coordinates or further information are given (Hedges et al. 1988:301). The Xuetian village site has yielded "human remains," and this site is indirectly dated to 24,000 BP (Hedges et al. 1988:301; Table 3).

\section{Chaoyang Xigou (Quwo)}

Chaoyang Xigou site, not far from Quwo City, southwest Shanxi Province, is located in a valley (Figure 1). Discovered in 1956 and excavated in 1983, fossils and 514 artifacts were found in layer 2 , the "cultural layer" (0.9-m-thick coarse sand and silt with calcareous nodules and some small gravel stones; fossil- and artifact-bearing sediment identified as "clay," see Liu 1986: Figure 2) of the third terrace of the Fuhe (Fu River). A right upper deciduous modern H. sapiens canine was found associated with 8 animal species, including 5 mammals (e.g. C. antiquitatis), and plant remains. A Late Pleistocene age estimate by Liu (1986) is with reference to geological, geomorphological, and faunal analyses (and see Wu and Poirier 1995:183-4). A ${ }^{14} \mathrm{C}$ date is $~ 33,000 \mathrm{BP}$; there is no information on the depositional provenance of the dated sample (Hedges et al. 1988:301).

\section{Undated Human Fossils}

\section{Maludong (Mengzi)}

Maludong in Mengzi County, is a limestone cave site in southeast Yunnan Province found during excavation in 1989 (Figure 1). It has yielded one of the largest collections of modern H. sapiens specimens in China, and contains a (possible) cut-marked and drilled individual ("Skull I") and a perhaps burnt individual ("Skull II"). The cave roof is no longer existent. Three layers were recognized (from top to bottom: layer 1: 4.5-m-thick sandy clay; layer 2: 5.0-m-thick "gray cultural layer," includes "cemented blocks and thin layer of red clay"; layer 3: unknown depth, limestone blocks). The majority of the human fossils derive from the upper part of layer 2, with most of the mammalian and plant fossils found in the northern area and 89 lithic and 14 antler artifacts in the 
southern area of layer 2. Evidence of fire (carbon particles, burnt bones and stones, red burnt clay, and hearths) appears to derive from layer 2 (Wu and Poirier 1995:208-9). The non-human fossils comprise 16 or 17 species (including Muntiacus muntjak and the extinct Axis cf. yunnanensis). The human cranial and post-cranial fossils have an MNI of 3-5 (Skull I: frontal and parietals; Skull II: 2 parietal fragments; "Skull III": glabellar part of frontal bone and occipital fragment; "Skull IV": frontal fragment; 2 mandible fragments (2 individuals, including a juvenile with $\mathrm{DM}_{2}$ ); right $\mathrm{M}^{3}$ and right $\mathrm{PM}^{2}$; femur fragment; and a tibia fragment). Only 1 mammalian species is extinct, and the age estimate of the fauna ranges from Late Pleistocene to Early Holocene (Zhang et al. 1991 in Wu and Poirier 1995:207-9).

\section{Chuandong}

Excavations of the cave site of Chuandong in Puding County, west Guizhou Province, from 1978 to 1982, yielded modern human fossils and lithic and bone artifacts (Figure 1). According to Yu (1984 in Wu and Poirier 1995:203), the "deposits were disturbed in recent years." "Skull I" was found in 1979 and "Skull II" in 1982 (Wu and Poirier 1995:200). One of the "skulls" and "the cultural remains" were found at a $1.50 \mathrm{~m}$ depth below the ground surface (Zhang 1980 in Wu and Poirier 1995:203). Higher up in the deposit, at $0.30 \mathrm{~m}$ below the ground surface, lithic artifacts, burnt bones, and ashes were discovered in what is referred to as "the cultural layer" (Wu and Poirier 1995:203). More human fossils derive from a disturbed clay layer at the entrance of the cave at $1.20 \mathrm{~m}$ depth under the surface (Wu and Poirier 1995:200).

The modern $H$. sapiens fossils represent 2 individuals (Skull I: a calotte with part of the nasal bones and, presumed to be part of the calotte, a right fragment of a maxilla with middle and lateral incisors and canine [Yu 1984 and Huang 1989 in Wu and Poirier 1995:200]; Skull II: a calotte [Wu 1989: Plate V:4]). Three human fossils are from the entrance area (a right median incisor, a mandible fragment with $\mathrm{M}_{1}, \mathrm{M}_{2}, \mathrm{M}_{3}$, and an isolated $\mathrm{M}_{2}$ ) (Wu and Poirier 1995:200-3).

\section{Dingmo Cave (Tiandong)}

Mammalian fossils, including a human tooth, from Dingmo Cave, Tiandong County, west Guangxi Zhuang Autonomous Region, were discovered about $85 \mathrm{~m}$ from the cave entrance at the end of the southern branch of the cave (Figure 1). There are 2 layers, and the fossils were found in the upper layer ( 0.50-m-thick sandy clay). Mammalian fossils were also found in the northern branch, and these are considered comparable to the southern branch fossils. A total of 13 species were identified (e.g. Ailuropoda melanoleuca and Palaeoloxodon namadicus). The human tooth (right $\mathrm{M}^{1}$ or $\mathrm{M}^{2}$ ) is very worn, rootless, and not heavily fossilized. A provisional Late Pleistocene age estimate is given by Li et al. (1984; see also Wu and Poirier 1995:219-20).

\section{Cave R5013 (Du’an)}

A large number of fossils, including 4 modern human teeth (left $\mathrm{M}^{1}$ or $\mathrm{M}^{2}$, left $\mathrm{M}^{3}$, right $\mathrm{M}_{1}$ or $\mathrm{M}_{2}$, and right $\mathrm{DM}_{2}$ ), were discovered in 1977 at Cave R5013 in Du'an County, west Guangxi Zhuang Autonomous Region (Figure 1). This cave had previously been dug for fertilizer, and the human fossils are from a disturbed area in Chamber II. Investigation indicates that the deposits and fossils had been washed into the cave. The upper part of the fossiliferous sandy clay $(0.70 \mathrm{~m}$ thick $)$ is inferred to identify the human fossil layer. This layer is overlain by a $0.3-0.5$-m-thick travertine; a molluskcontaining 0.12 -m-thick loam layer; a 0.02 -m-thick travertine; and a 0.20 -m-thick clay layer. The 38 animal fossil taxa include 35 mammalian taxa (including $H$. subcristata and 14 carnivore sp.; mainly rootless teeth). They are referred to a Late Pleistocene time period (Zhao et al. 1981 in Wu and Poirier 1995:213-5). 


\section{Guoshandong (Zhaotong)}

Fossils and very small pieces of carbon were found during a survey of the limestone cave of Guoshandong in Zhaotong municipality, north Yunnan Province, in 1982 (Zheng 1985; Figure 1). The fossils were recovered from layer 5 , the lowest layer ( 0.40-m-thick yellow coarse and cemented sandy clay). This layer lies about $0.80-0.90 \mathrm{~m}$ below the disturbed cave surface (layer $1, \sim 0.20 \mathrm{~m}$ thick). The human fossil is a left $\mathrm{M}_{2}$ lacking most of its root. The Late Pleistocene age estimate is based on the associated mammalian fauna (5 species, including Stegodon sp.) (Zheng 1985; see also Wu and Poirier 1995:225).

\section{Huanglong [Shaanxi Province]}

Close to the edge of the southern slope of Xujiafenshan, Huanglong County, north Shaanxi Province, human cranial fragments were found in the course of reservoir construction in 1975 (Figure 1). There are 5 layers (layers 5 to 1 , top to bottom). The human remains and a Pseudaxis sp. antler were located at the boundary of layer 5 (red clay) and layer 4 (yellow clay), both $6 \mathrm{~m}$ thick and with calcified concretions. Layer 5 is a secondary deposit; pottery was found on the surface (Wang and Li 1983; see also Wu and Poirier 1995:176). Fragmentary mammalian fossils were found in layer 2 (8-m-thick clay). The modern human parietal and frontal fragments were reconstructed to form a partial skullcap (see Wang and Li 1983: Plate 1), with a geological Late Pleistocene age estimate (Li and Wang 1983).

\section{Niujiagou (Jinchuan)}

Human fossils found in 1976 at the gully site of Niujiagou ("Jingchuan" in Li and Wu 2007), Jinchuan County, south Gansu, were discovered in a sandy clay layer with mammalian fossils and 88 lithic artifacts (Figure 1). The fossil layer is capped by Malan Loess and lies above Lishi Loess (Liu et al. 1984). The human fossils are a partial cranium (a right part of the frontal squama fragment, much of the right parietal, a left parietal fragment, a right temporal, and much of the occipital, see Liu et al. 1984: Plate I:1) and diagnosed as modern H. sapiens ( $\mathrm{Li}$ and Wu 2007; Wu and Poirier 1995:176). The age estimate is based on the associated cultural remains and the mammalian fossils (5 species, including Equus sp.), particularly Myospalax fontanieri, with a suggested age of either $\sim 50,000-37,000$ or $\sim 28,000$ yr with reference to the Salawusu and Shiyu dates, respectively (Liu et al. 1984).

\section{Hulidong (Qingliu)}

A human fossil tooth (left $\mathrm{M}_{1}$ ) discovered in 1988 at Hulidong, Qingliu County, west Fujian Province, was found in layer 3 (0.60-0.80-m-thick sandy soil and fine gravel) with mammalian fossils (6 species, including M. augustus and S. scrofa) (You et al. 1989; see also Wu and Poirier 1995:228; Figure 1). Six layers (top to bottom: layers 6-1) were recognized. The cave surface is disturbed. Close to where the human tooth and some of the other fauna were found, the intrusive silt layer 6 was identified (see You et al. 1989). In 1989, 5 modern H. sapiens fossil teeth (right inner upper incisor; right upper canine; left inner lower incisor; left $\mathrm{M}_{1}$; right $\mathrm{M}_{2}$ ) and 17 species of fauna were recovered from layer 3 (Dong and Fan 1996). The age of the modern $H$. sapiens fossils is estimated to be late Late Pleistocene with reference to the fauna (You et al. 1989; Dong and Fan 1996).

\section{Wuzhutai (Xintai)}

After the discovery of a human left lower molar fossil by farmers in 1966 near Wuzhutai village in Xintai County, central Shandong Province, reportedly in a limestone fissure, Wu Xinzhi (IVPP) and Shandong Provincial Museum discovered mammalian fossils in the same fissure (6 species, including C. antiquitatis and Sus sp.) (Wu and Zong 1973 in Wu and Poirier 1995:185; Figure 1). 
10. Nalai

The only fossil-bearing layer of Nalai Cave, discovered in 1984, in Longlin County, west Guangxi Zhuang Autonomous Region (Figure 1), is layer 1 (0.10-0.30-m-thick clay), the undisturbed surface layer of the posterior chamber. Five layers were identified with the base not reached (known depth of cave deposit is $0.28-0.50 \mathrm{~m}$ ). Two human teeth (left $\mathrm{M}^{2}$, left $\mathrm{M}_{2}$ ) were found. There are 14 species of mammalian fossils (including $H$. subcristata and $R$. sinensis) on which basis a Late Pleistocene age is indicated (Peng et al. 1987 in Wu and Poirier 1995:215-7).

\section{Taohua}

In 1983, excavation of Taohua Cave in Linzhi (or Guiyang) County, central Guizhou Province, discovered mammalian fossils, including a human femur, and lithic, bone, and shell artifacts (Figure 1). These were found at the bottom of a black clay horizon and in the top part of a yellow clay horizon with a depth of $0.70-1.50 \mathrm{~m}$. Also found was an ash layer (0.40-0.70 m thick) with burnt bones, stones, and small carbon fragments. The Late Pleistocene fauna comprises more than 5 species (including Megatapirus sp. and Bison sp.) (Cao 1984 in Wu and Poirier 1995:210).

\section{Dongzhongyan}

Mammalian fossils, including 2 modern human teeth (right $\mathrm{PM}^{2}$, right $\mathrm{M}_{3}$ ), one of which was found during a survey in 1978 (Qiu et al. 1986) and the other excavated in 1989, are from the cave site of Dongzhongyan, Fengkai County, east Guangdong Province (Song et al. 1991 in Wu and Poirier 1995:226-7; Figure 1). Six layers were identified (layers 1-6, top to bottom, total thickness 0.76$1.53 \mathrm{~m}$, no depth information is available for the lowest layer) with the fossils recovered from layer 5 (0.30-0.70-m-thick clay). The animal fossils (24 species, including $H$. subcristata and S. orientalis) indicate an early Late Pleistocene (Qiu et al. 1986) or Late Pleistocene age (Song et al. 1991 in Wu and Poirier 1995:225-7).

\section{Shuiyan Dongdong (Lipu)}

A human tooth (left $\mathrm{PM}_{2}$ ) and 5 mammalian species (e.g. Hystrix cf. subcristata, A. melanoleuca fovealis) were found in an undisturbed part of Shuiyan Dongdong, Lipu County, northeast Guangxi Zhuang Autonomous Region (Figure 1). Most of the cave's deposits had been disturbed previous to the discovery except for the fossil layer. There are few details on the stratigraphy. A sandy clay layer situated below "stalactic columns" is the fossil layer. The fauna points to a Late Pleistocene age (Wu et al. 1962 in Wu and Poirier 1995:220).

Table 4 Potential materials for AMS ${ }^{14} \mathrm{C}$ dating of some Chinese early modern $\mathrm{H}$. sapiens sites without radiometric dates.

\begin{tabular}{|c|c|c|}
\hline Site & Materials & Other materials \\
\hline Maludong & Human bones and/or teeth & $\begin{array}{l}\text { Non-human fossils, carbon, but strati- } \\
\text { graphic relationship to human fossils un- } \\
\text { clear and fossil layer } 5 \text { m thick }\end{array}$ \\
\hline Chuandong & Human bones and/or teeth & None \\
\hline Dingmo Cave & Human tooth & Non-human fossils \\
\hline Guoshandong & Human tooth & Non-human fossils; enough carbon? \\
\hline Huanglong (Shaanxi) & Human bone & Pseudaxis sp. antler \\
\hline Jinchuan & Human bone & Non-human fossils \\
\hline Hulidong & Human tooth & Non-human fossils \\
\hline Baojivan & Human teeth & Non-human fossils \\
\hline
\end{tabular}




\section{Unknown Locational or Stratigraphic Context: Dated Human Fossil Site}

Discovered in 1974 and excavated in 1975, the cave site of Maomaodong, Xingyi County, south Guizhou Province, yielded 10 fossil mammalian species, including modern $H$. sapiens, associated with 1121 lithic artifacts and 14 bone and antler tools (Figure 1). The unstudied human remains comprise 7 elements ( 2 mandibles, right mandible fragment, anterior mandible fragment, and 3 femoral fragments (Cao 1982 in Wu and Poirier 1995:209-10). The site was dated by U-series to 14,600 \pm 1200 yr (Zhang 1983 in Wu and Poirier 1995:209).

Unknown Locational or Stratigraphic Context: Undated Human Fossil Sites

\section{Longlin}

A cave in the vicinity of De'e town in Longlin County, northwest Guangxi Zhuang Autonomous Region (Figure 1), had been emptied of most of its deposits for fertilizer prior to the discovery and excavation in 1979 of a modern human skull (not found were the mandibular ramus, a small portion of the mandible's front part, and both $\mathrm{M}_{1} \mathrm{~s}$ ) and post-cranial bones (a rib, vertebrae, limb bones). Also found were particles of carbon, ashes, burnt clay, and animal bone, the latter too fragmented to establish their taxonomy. Breccia was also found. A “deep-brown hard deposit" was located on the cave wall and on the human specimens (Zhang and Li 1982 in Wu and Poirier 1995:199-200).

\section{Antu}

A modern human premolar fossil, discovered in 1964, was reportedly found in a large limestone cave exploited as a quarry (the Shimenshan quarry) close to the town of Mingyue in Antu County, east Jilin Province (Figure 1). There is no stratigraphic information, and the cave is no longer existent due to quarrying. The report by Jiang (1982) suggests that the tooth could be from a similar gray loam horizon, layer 3, identified in a smaller cave discovered in 1973 and $~ 9 \mathrm{~m}$ distance from the large cave; the small cave has 4 layers, all with fossils (Jiang 1982 in Wu and Poirier 1995:185-6).

\section{Changwu}

A rootless modern human tooth (most likely an erupting left $\mathrm{M}^{2}$ ) and other fossils found amongst mammalian fossils for sale by resident farmers in 1972 are presumed to derive from Yaergou (Duck Gully), one of 2 Late Pleistocene fossil sites near Changwu City, east-central Shaanxi Province (Figure 1). This site contains 8 layers (layers $8-1$ top to base, total depth of $36 \mathrm{~m}$ ) with 3 fossil layers: layer 5 (2 $\mathrm{m}$ of sandy clay); layer 4 (10 $\mathrm{m}$ of sandy clay); and layer 3 ( $2 \mathrm{~m}$ of fine sandy clay). Lithic artifacts were found in layer 5 (Huang and Zheng 1982). The fragmentary fauna of 7 species (including Myospalax sp., Coelodonta sp.) is of Late Pleistocene age (Huang and Zheng 1982; and see Wu and Poirier 1995:184-5).

\section{Mujiajiao (Lijiang)}

During construction of an irrigation canal near Mujiajiao village, Lijiang County, north Yunnan Province, a modern human cranium was discovered by a farmer in 1964 (Wu and Poirier 1995:2035; Figure 1). Examination of the locality identified 5 layers ( 4.2 $\mathrm{m}$ thick) and excavation of the canal banks recovered mammalian fossils (6 species, including Stegodon sp., Bibos gaurus) and 6 lithic artifacts (Lin and Zhang 1978, reprinted in Yunnan Provincial Museum 1991; Wu and Poirier 1995:205). The cranium lacks part of the face and parts of the left temporal (mastoid and tympanic) and occipital (basal and lateral). Some coarse sand attached to the human cranium may indicate its derivation from the Late Pleistocene 1-m-thick gravel layer 4 (Yunnan Provincial Museum 1977 in Wu and Poirier 1995:205). 


\section{Jianpin}

A right humeral shaft without ends was identified by Sun Shuodao of the Liaoning Provincial Museum in a collection of bones at Jianpin Cooperative in west Liaoning Province in 1957 and transferred to the Institute of Vertebrate Paleontology and Paleoanthropology in Beijing (Figure 1). Wu and Poirier (1995:180-1) mention collections of mammalian fossils (5 species, including $C$. antiquitatis) made earlier in the same year by the Liaoning Provincial Museum, and appear to suggest a possible connection between the $H$. sapiens femur and the mammalian fossils, the latter interpreted as of Late Pleistocene origin.

\section{Directly Dated and Formerly Presumed Pleistocene Modern Human Fossil: Xarus (Ordos)}

Mammalian fossils, including modern $H$. sapiens, and lithic artifacts were discovered in 1922 and 1923 and 1956 to 1980 at several localities in the Xarus Valley (formerly known as Salawusu and Sjara-osso-gol), southeast Ordos Plateau, Inner Mongolia Autonomous Region (e.g. Licent and Teilhard de Chardin 1925; Licent et al. 1927; Huang and Wei 1981; Figure 1). Most of the 23 human cranial and post-cranial bones are surface collections and from recent fluvial deposits (Huang and Wei 1981). A series of ${ }^{14} \mathrm{C}$ and U-series dates generated for several localities in the Ordos place the modern human specimens and artifacts between $~ 30,000-50,000$ yr old (CASS 1991:63; Chen and Yuan 1988; Yuan et al. 1983; Table 3). The low fluorine content (0.38\%) of a partial human femur (PA 62) found on the surface during a survey in 1923 (Licent et al. 1927; Wei 2005) compared to mammalian fossil bone (1.10\%), indicated a younger age for the femur (Chiu 1955). Direct AMS ${ }^{14} \mathrm{C}$ dating produced very recent dates of $220 \pm 30 \mathrm{BP}$ (AA-55454) and post-bomb (AA-55453) (Keates et al. 2007) and $275 \pm 25$ BP (KIA-23614) and $210 \pm 25$ BP (KIA-23614) (Shang et al. 2006).

\section{Questionable Homo sp. Fossil}

Excavation in 1982 at Longtanshan Site 2, Chenggong County, central-west Yunnan Province (Figure 1), recovered mammalian fossils, including a human tooth (left $\mathrm{DM}_{2}$ ), and 107 lithic artifacts from layers 2 and 4, and burnt bones from layer 4 . There are 4 layers at this site (4.3 m thickness, including a 1-m-thick surface deposit) with layers 2 and 4 (1- and 2-m-thick sandy clay, respectively) separated by the 0.3 -m-thick layer 3 travertine; layers 2 and 4 are considered to be of similar age. Four mammalian species were found (e.g. R. sinensis) (Qiu et al. 1985). However, according to Wu and Poirier (1995:231), who list the human tooth in their anatomically modern human chapter, its "very atypical...morphology..." (see Qiu et al. 1985: Plate I:1) precludes definite attribution to Homo sp. Another opinion, based on the published photograph, is that the tooth has an atypical morphology (Marquez-Grant, personal communication, 2010). A ${ }^{14} \mathrm{C}$ determination dates layer 4 (Qiu et al. 1985) to 29,000 BP (Qiu et al. 1985; CASS 1991:240; Table 3).

\section{KOREA}

This section is based on Norton's (2000) review of Korean paleoanthropology. Nine sites with hominid fossils have been identified on the Korean Peninsula. Of these, most are modern human sites (Norton 2000: Table 3), amounting to 7 sites, including Ryonggok Cave (see below). The majority are located in South Korea. All are indirectly dated sites.

In North Korea, 2 modern human sites have been identified. The Ryonggok Cave site, located near Pyongyang, has yielded the largest set of hominid fossils in Korea (Figure 1). Hominids (MNI 5) were found in layers 9-12 (top to bottom), referred to as cultural layers: layer 9 (a cranium and 3 mandibles); layer 10 (a cranium, 2 mandibles, and a femur); layer 11 (several skull fragments and 16 post-cranial bones); layer 12 (a maxilla). The morphology of the partially reconstructed Ryonggok 
cranium No. 7 (layer 9), classified as Homo cf. sapiens by Sohn (1992, in Norton 2000, and see references cited therein), identifies it as a modern H. sapiens (see Norton 2000: Figure 2), as I pointed out in my review of Norton's (2000) manuscript. Norton (2000:814) argues that until more complete analysis of the specimen and a mandible is carried out, “...an archaic $H$. cf. sapiens designation is more applicable.” The most reliable age estimate for the Ryonggok site is a 46,000-48,000 yr Useries date for layer 9. At the Kumchon Cave site, human fossils (mandible, tooth, 5 vertebrae) are thought to be about 30,000-35,000 yr old based on the fauna (Norton 2000; Figure 1).

In South Korea, 5 modern human sites have been found. The Mandalli site (cranial fragment, mandible, partial humerus) has a Late Pleistocene age estimate. The Sangsi Rockshelter (4 cranial fragments, teeth, and 3 post-cranial bones) was dated by U-series to $~ 30 \mathrm{ka}$. The faunal age estimate of 40,000-50,000 yr for the Hungsugul (Turubong Cave Complex) site human (an almost complete skeleton) is subject to debate (see Norton 2000:813). At the Chommal Cave site, human fossils (several post-cranial bones) are from level IV (0.50 m thick) or from the overlying level V(?), and have a $~ 40,000$ yr U-series age for level IV. The Kunanggul site (3 post-cranial bones) has a Late Pleistocene faunal age estimate (Norton 2000; Figure 1).

\section{JAPAN}

There are about 16 sites in Japan where hominids of Late Pleistocene age have been discovered. Of these, 8 sites are in the Ryukyu Islands, 1 on Kyushu Island, and 7 on Honshu Island. The majority of sites are limestone caves and fissures, and these are most common in the Ryukyu Islands (Matsu'ura 1996; Ono et al. 1999). However, over 50\% of the "Pleistocene" hominid sites are thought to be from later time periods, including the Mesolithic (Kondo and Matsu'ura 2005:155 and references therein). Bones are often not well preserved in Japanese sites and Pleistocene sites are small (e.g. Serizawa 1979).

\section{Directly Dated Human Fossils}

At the Negata limestone quarry site (also known as Hamakita site), Hamakita City, east central Honshu island, human bones were found in fissure fillings from 1960 to 1962 (Figure 1). The provenance within the fillings cannot be reconstructed. The human bones were assigned to different chronological groups, the Upper Layer (cranial fragments; right $\mathrm{M}_{3}$; right clavicle, right ulna, and right ilium fragments; and partial right humerus) and the Lower Layer (right tibia fragment), with reference to fluorine analysis, degree of mineralization, color, and geological environment. Based on the large quantities of mammalian fossils found in the "Homo bed" and the older "Felis bed," it was inferred that the human fossils could originate from these horizons (Kondo and Matsu'ura 2005: 155). The fluorine contents of 4 human bones from the Upper Layer (0.437-0.569\%) and the Homo bed non-human bones $(0.461-0.498 \%)$ are similar. The human bone from the Lower Layer $(0.997 \%)$ is within the range of the Felis bed non-human mammals (0.771-1.075) (Kondo and Matsu'ura 2005).

The different ages indicated by the fluorine analysis was to some extent confirmed by AMS ${ }^{14} \mathrm{C}$ dating. The 3 human bones selected from the Upper Layer gave ${ }^{14} \mathrm{C}$ dates of $13,000-14,000 \mathrm{BP}$. The human bone from the Lower Layer contained insufficient gelatin for ${ }^{14} \mathrm{C}$ dating (Kondo and Matsu'ura 2005; see Table 5). The similar fluorine contents of the Lower Layer human bone (0.997\%) and Panthera cf. pardus (0.902\%) from the Felis bed, leads Kondo and Matsu'ura (2005) to argue that the ${ }^{14} \mathrm{C}$ date for the latter $(17,910 \pm 70 \mathrm{BP}$, Beta-94983, sample HK-B-8) likely approximates that for the human bone. Previous age estimates for the Upper and Lower Layer were of $\sim 15,000$ and 18,000 BP, respectively (Matsu'ura and Kondo 2000 in Matsu'ura and Kondo 2001: 286; Ono et al. 1999). 
Table 5 Direct AMS ${ }^{14} \mathrm{C}$ dates for modern $H$. sapiens from the Negata and Shiraho-Saonetabaru Cave sites, Japan.

\begin{tabular}{|c|c|c|c|c|}
\hline Locality, layer & Sample & Age & Lab nr & Reference \\
\hline Negata, Upp & $\begin{array}{l}\text { HKH-U-PR } \\
\text { (parietal) }\end{array}$ &, $050 \pm 50$ & Beta-160571 & $\begin{array}{l}\text { Kondo and Matsu'ura } \\
\text { (2005) }\end{array}$ \\
\hline Nega & $\begin{array}{l}\text { HKH-U-OC } \\
\text { (occipital) }\end{array}$ & $14,200 \pm 50$ & Beta-160572 & $\begin{array}{l}\text { Kondo and Matsu'ura } \\
\text { (2005) }\end{array}$ \\
\hline Negata, Upper Layer & $\begin{array}{l}\text { HKH-U-HM } \\
\text { (humerus) }\end{array}$ & $13,860 \pm 50$ & Beta- 160570 & $\begin{array}{l}\text { Kondo and Matsu'ura } \\
\text { (2005) }\end{array}$ \\
\hline $\begin{array}{l}\text { Shiraho-Saonetabaru } \\
\text { Cave }\end{array}$ & $\begin{array}{l}\text { No. } 2 \\
\text { (right parietal) }\end{array}$ & $20,416 \pm 113$ & MTC-12820 & Nakagawa et al. (2010) \\
\hline $\begin{array}{l}\text { Shiraho-Saonetabaru } \\
\text { Cave }\end{array}$ & $\begin{array}{l}\text { No. } 4 \\
\text { (metatarsal) }\end{array}$ & $18,752 \pm 100$ & MTC-13228 & Nakagawa et al. (2010) \\
\hline $\begin{array}{l}\text { Shiraho-Saonetabaru } \\
\text { Cave }\end{array}$ & $\begin{array}{l}\text { No. } 8 \\
\text { (right fibula) }\end{array}$ & $15,751 \pm 421$ & MTC-12818 & Nakagawa et al. (2010) \\
\hline
\end{tabular}

Indirectly Dated Human Fossils

\section{Minatogawa}

Modern human fossils from the Minatogawa limestone quarry, a fissure site close to the southern coast of Okinawa Island, southern Japan, were first discovered in 1966 with excavations conducted in 1968, 1970, and 1974 (Suzuki and Tanabe 1982; Figure 1 and see below). All the human fossils found in 1970-71 are adults (M I (Minatogawa 1), almost complete skeleton; M II and M III, partial crania; M III, "skull” (lost); M A, B, C, and D, mandible fragments; MNI is 5-9 (Suzuki 1982) and about 178 post-cranial bones (see Baba and Endo 1982: Figures 4.1-4.5).

Fluorine analyses of 8 of the human fossils and a comparative sample of mammalian bones from the same site showed a fluorine content of the human specimens (0.87-1.65\%) similar to the deer fossils (0.98-1.68\%) with an indicated age of terminal Pleistocene, with the human fossils belonging to mammalian Phase a or transitional Phase a-b (Matsu'ura 1982). ${ }^{14} \mathrm{C}$ dates of charcoal fragments found in the lower deposit are 18,250 $\pm 650 \mathrm{BP}$ (TK-141) and 16,600 $\pm 300 \mathrm{BP}$ (TK-142), but the depositional relationship of the dated samples to the human fossils is not known (Matsu'ura 1982; and see Suzuki and Tanabe 1982). A U-series date (non-destructive gamma-ray) of one of the human crania is 19,200 \pm 1800 yr ago (Yokoyama 1992 in Matsu'ura 1996:183, 185).

\section{Upper Minatogawa}

Found in 1968, before the first excavation in 1968, 9 postcranial bones (MNI is 3) were discovered at the Minatogawa limestone quarry and are thought to have their origin in the upper horizons. The fluorine content of these bones partly corresponds with those of the Minatogawa human fossils, with indications that the former may be somewhat younger (late Phase a to early Phase b). Dates of (animal) bones by aspartic acid racemization may point to an age of at least 12,000 yr (late Phase b) for the human fossils (Matsu'ura 1996; Figure 1).

\section{Yamashita-cho Cave I}

Two modern human subadult fossils were excavated from a cave in Naha-shi (Naha City), southwest Okinawa, in 1968 (Figure 1). Four Pleistocene layers (III-VI) were identified, and the human bones (femur and tibia, most of) were found near the top of layer IV with deer fossils. Deer fossils, lithic and deer bone artifacts, and charcoal are from level III (Trinkaus and Ruff 1996 and references 
therein). According to the excavators (Takamiya et al. 1975 in Matsu'ura 1996:186), the human bones are from the top of layer VI and were located immediately below the "charcoal lens intercalations" of layers III and V. The charcoal lenses are believed to "belong to the same layer" (Takamiya et al. 1975 in Matsu'ura 1996:186). A ${ }^{14} \mathrm{C}$ date on the charcoal is 32,100 $\pm 1000 \mathrm{BP}$ (TK-78), which would date the human bones to $>32,000 \mathrm{yr}$ (Trinkaus and Ruff 1996 and references therein).

\section{Pinza-abu}

Modern human fossils (parietal, occipital, teeth, and postcranial fragments) from Pinza-abu, Miyako island, were discovered from 1979-83 (Figure 1). The human fossils from this cave site were associated with locally extinct animal fossils in a clay and gravel layer, partly covered by calcareous flowstone. Charcoal fragments were also found in the fossil layer. The fluorine contents of the "human skull" and deer bones are similar, while ${ }^{14} \mathrm{C}$ dates on charcoal yielded dates of 25,800 \pm 900 BP (TK-535) and 26,800 \pm 1300 BP (TK-605). An asparitic amino-acid racemization date of deer bones is 20,000 yr old (Matsu'ura 1996:187; and see Ono et al. 1999).

\section{Shimojibaru Cave}

A partial modern human infant skeleton, recovered in 1982-83 and 1986 with non-extant deer fossils and other mammals, is from a clay layer located below a calcareous layer at Shimojibaru Cave on Kume Island (Figure 1). A ${ }^{14} \mathrm{C}$ date on crab fossils, also from the clay layer, is 15,200 $\pm 100 \mathrm{BP}$, and racemization study of a cervid bone, would indicate an estimated age of 15,000-16,000 yr (Matsu'ura 1996).

\section{Ushikawa}

At the Ushikawa limestone fissure site in Toyohashi City, Aichi Prefecture, Honshu Island (Figure 1), a left humerus shaft fragment and a left femoral head and fauna were discovered in 1957 and 1959, respectively. However, the humerus has now been shown to be non-human (e.g. Matsu'ura 1996:189). The fauna is of Late Pleistocene age (Matsu'ura 1996; Ono et al. 1999). In initial ${ }^{14} \mathrm{C}$ dating [and fluorine studies?], the date of the human fossil is more than 16,000 BP (Matsu'ura 1996).

\section{Human Fossils That May Date to the Late Late Pleistocene}

\section{Ryukyu Islands: Ie island}

At Kadabaru Cave, parietal fragments were found in 1962 (Matsu'ura 1996; Figure 1). In the lower branch of Gohezu Cave, a left mandible fragment (and perhaps other human fragments, see Ono et al. 1999) were discovered in 1976. The bone is "well-fossilised" and was apparently found with cervid fossils (Matsu'ura 1996; Figure 1).

\section{Honshu Island}

A right human mandible discovered in 1969 on Yomigahama beach, Sakaiminato City, Tottori Prefecture, derives from an approximately 6-m-thick marine sand layer (Matsu'ura 1996; Ono et al. 1999; Figure 1). A number of archaic characteristics are thought to be indicative of an early Jomon time period age (Hanihara 1995 in Matsu’ura 1996:188).

\section{Kyushu Island}

At Hijiridake Cave, Oita Prefecture, a modern human parieto-occipital fragment ("Man 1") was excavated in 1962 from the upper part of layer 3 (Serizawa 1979:343; Matsu'ura 1996; Figure 1); layer 3 ( $<0.25$-m-thick clay) also contained lithic artifacts on the upper surface (Serizawa 1979: 
343). A human left talus bone has also been reported from layer 3 (Ono et al. 1999), but this bone was collected from the surface according to Matsu'ura (1996). More "skull fragments" ("Man 2") may derive from layer 3 (see Matsu'ura 1996:188). The estimated age is 13,000-14,000 yr with reference to the artifacts (Ono et al. 1999). The fluorine contents of the Man 1 and Man 2 bones ( $0.56 \%$ and $0.55 \%$, respectively) are higher than the layer 1 medieval human bone $(0.20 \%)$.

\section{Human Fossils That May Date to the Late Late Pleistocene or Holocene}

1. Ryukyu Islands

A calotte was discovered at the Tobaru Cave, Chatan village, in 1966 (Matsu'ura 1996; Figure 1).

2. Honshu Island

In the course of road construction in 1967, a human cranium was found at Tomari Cave, Himi City, Toyama Prefecture, followed by a human rib fragment discovery in 1972. The fluorine content indicates either an Early Holocene or late Late Pleistocene age for the human bones, while morphological analysis compares the cranium to Initial/Early Jomon skulls (Matsu'ura 1996; Ono et al. 1999; Figure 1).

\section{Human Fossils That May Date to the Late Pleistocene}

In 1964, a right mandible fragment found by non-professionals at Oyama Cave, Ginowan City, Ryukyu Islands, "probably" dates to the Pleistocene based on its geological context, the extent of fossilization, and fluorine content; this specimen is considered to be older than either Kadebaru or Tobaru (Matsu'ura 1996:186; Figure 1).

\section{Human Fossils That May Date to the Early Late Pleistocene}

Four modern human bones have been found at the Kuzuü town sites in Aso-gun, Tochigi Prefecture, Honshu Island: a left femur fragment at the Maegawara Lower Cave and a right femur fragment from near the Maegawara Lower and Upper Caves, both discovered in 1951. A metacarpal fragment was found in 1984 near the Maegawara Lower and Upper Caves. A right ulna fragment was retrieved from a collection and may derive from the Upper Kuzuü Formation fossiliferous fissure sediments. These sediments are located below a 10-m-thick breccia, which is overlain by the Kanuma Pumice Bed. Fission-track dates on hornblende from the pumice are 32,000 \pm 4000 and $31,000 \pm 8000$ yr with the fissure sediments estimated to date to the early Late Pleistocene. However, Matsu'ura (1996) is not convinced of the reliability of these dates given difficulties with the method of dating (Figure 1).

\section{Directly Dated and Formerly Presumed Pleistocene Modern Humans: Mikkabi}

Five human cranial fragments, a partial right pelvis, and a right femur shaft (Matsu'ura 1996) from the Tadaki Quarry at the site of Mikkabi, Shizouka Prefecture, Honshu Island, found in 1959 and 1961 (Figure 1), were previously considered to date to the Late Pleistocene with reference to extinct mammalian species and biostratigraphic comparison (Palaeoloxodon naumanni, Sinomegaceros sp.) from the same site (Suzuki 1962; Takai 1962 in Matsu'ura and Kondo 2001). U-series dating of 2 or 3 of the human bones (see Matsu'ura and Kondo 2001:278) returned ages of $\sim 9100, \sim 13,400$, 17,300 \pm 1500, and 20,900 yr (Yokoyama 1992 in Matsu'ura and Kondo 2001). Results of fluorine analysis of 3 of the human bones (No. 1 frontal, No. 6 pelvis, and No. 7 femur) by Matsu'ura and Kondo (2001), found that these were generally comparable to previous fluorine values (Tanabe 1962, in Matsu'ura and Kondo 2001). All of the 4 direct AMS ${ }^{14} \mathrm{C}$ dates of the 3 human bones (see 
above) are within the Early Holocene [frontal (MBH-1): $9330 \pm 40$ BP (Beta-135470); pelvis (MBH-6 (1) and MBH-6 (2): $7500 \pm 50$ BP (Beta-155913) and $7450 \pm 40$ BP (Beta-156757); femur (MBH-7): $9540 \pm 60$ BP (Beta-142912)] (Matsu’ura and Kondo 2001).

\section{DISCUSSION}

The only directly dated Pleistocene modern human fossils in East Asia are from Tianyuandong in China with an age of $\sim 34,000$ BP and from Negata in Japan with a (minimum) age of $\sim 14,000$ BP. Modern human fossils discovered recently in the Shiraho-Saonetabaru Cave, Ishigaki Island, Okinawa, in Japan, have been directly dated with the oldest date of 20,000 BP (Nakagawa et al. 2010; Table 5).

Considering the fact that ${ }^{14} \mathrm{C}$ dating has been in operation in Chinese laboratories since 1965, it would have seemed a useful method to date many more Pleistocene sites than is actually the case. One explanation why human bones and teeth have not been directly dated is because human fossils of Pleistocene or presumed Pleistocene age are treated as too precious for conventional ${ }^{14} \mathrm{C}$ dating, requiring a relatively large amount of material. Now that AMS ${ }^{14} \mathrm{C}$ dating has become available, requiring very small amounts of material (about $0.5-1 \mathrm{~g}$, see Higham et al. 2006), Chinese workers may be more willing to submit human material for direct dating. Even so, the reluctance to directly date human specimens may also stem from a certain apprehension in that direct dates might not confirm an accepted old age (middle to late Late Pleistocene) for early modern humans in China. There is certainly no lack of human fossils that could be dated with an approximate MNI of 65 (Keates, unpublished data, and see above). The 9 modern human sites on the Korean Peninsula are all indirectly dated based on U-series and faunal age estimates to the later Late Pleistocene. The majority of the 16 sites in Japan are also indirectly dated based on ${ }^{14} \mathrm{C}$, U-series, and fission-track dates, and fluorine, geological, and faunal studies.

Although some regard fluorine analysis as an outmoded tool for dating (Shen Guanjun, personal communication, 2005), direct AMS ${ }^{14} \mathrm{C}$ dating of the Xarus femur confirmed a young age previously inferred from its low fluorine content. The low fluorine content of the Huangshanxi (Ziyang) cranium would also seem to indicate, together with the Holocene ${ }^{14} \mathrm{C}$ dates of the fossil fauna, that Huangshanxi is not of Pleistocene origin. Negata is a case in point of current attempts in Japan to ascertain the age of human specimens using fluorine analysis followed by ${ }^{14} \mathrm{C}$ dating.

The uncertain stratigraphic context of the Tongtianyan (Liujiang) human fossils prevents acceptance of the dates so far done (Chen and Zhang 1991; Brown 1998; Liu et al. 2006). The depositional context of the human specimens and the dated sample(s) of those specimens known to derive from a specific layer should take the thickness of a layer into account. For example, the Shiyu human occipital fragment is from an 0.9-1.5-m-thick layer of fluvial sands and gravel; there are no data where in this thick layer the human and the dated sample were found. Furthermore, the rate of soil accumulation has not been studied, and, therefore, the significance and relevance of the only dated sample from Shiyu with respect to the human specimen is unknown. A recent listing of ${ }^{14} \mathrm{C}$ dates for Chinese sites does not consider these factors (see Barton et al. 2007).

Table 4 (see above) lists several Chinese sites without absolute dates, suggesting samples for dating with preference given to the human samples. However, all of the sites lacking direct ${ }^{14} \mathrm{C}$ dates of human specimens should be dated in East Asia, not only those where a dated layer is very thick and the relationship of the dated sample to the human fossil(s) is not known, or not published. For the human specimens from the Ordos area, direct ${ }^{14} \mathrm{C}$ dating of the human specimens recovered in situ is now called for to establish their age (Keates et al. 2007). 
Because of their uncertain locational (Changwu, Jianpin) or stratigraphic (Antu, Mujiajiao, Yanjiagang) context, the age of these specimens is unknown. ${ }^{14} \mathrm{C}$ dating might establish the layer provenance and age of the Antu tooth by dating the latter and samples of fossils from the 4 layers in the small cave.

The application of U-series dating to Chinese human fossil sites has resulted in very early ages, most of which are early Late Pleistocene, for the first appearance of modern humans in China. Some of these dates would make some late archaic humans chronologically equivalent to early modern humans, including Xujiayao. The current application of U-series to date human specimens indirectly must consider the problems involved with this method, including the leaching of uranium from bones (e.g. Aitken 1994:130-1; Matsu'ura 1996).

The great discrepancy between the ${ }^{14} \mathrm{C}$ and U-series dates at Zhangkoudong begs the question of what should be dated: human presence as inferred by the dated charcoal or the presence of flowstone, a natural phenomenon? Or was the charcoal intrusive, i.e. moved from younger layers to layer 6 ? Similarly, can the discrepancy between the younger U-series dates of a deer tooth and the older flowstone U-series date (i.e. 44,000 yr) from Gaitoudong (Laibin) be reasonably explained by U migration of fossil bones, as argued by Shen et al. (2007)? And, furthermore, can the younger flowstone date (i.e. $~ 9000 \mathrm{yr}$ ) refer to a recent formation of this part of the flowstone layer? At Huanglongdong, Wu et al.'s (2006) argument of possible absorption and leaching of the single dated ESR sample would equally apply to the U-series dates. Considering the high carbon content of the charcoal, it would seem reasonable to conduct ${ }^{14} \mathrm{C}$ dating, also in view of the relatively young ESR date.

The unstudied human fossils in China (Shiyu MNI is 1, Laishui MNI is 1, Maomaodong MNI is 4) need to be examined to ascertain their morphology in detail. The identification of archaic morphological features on some of the modern humans from China is considered to be relevant to their chronology. Woo's (1959) study of Tongtianyan identified several features he considered as indicative of an earlier age (e.g. more posterior bregma position, relatively large supraorbitals) compared to later modern humans, including Shandingdong and Huangshanxi. A number of other researchers "dated" Tongtianyan to 20,000 yr by comparing it to the similar morphology of Minatogawa (e.g. Brown 1998; Wu 1988). Another detailed study by Liu et al. (2006) found that the Tongtianyan cranium is similar to the modern Chinese morphology. This, and questions about its exact provenance within the cave, do not lend credibility to the early date of $\sim 67,000 \mathrm{yr}$ (Liu et al. 2006). Kamminga and Wright (1988) refer the Shandingdong (Upper Cave) human fossils to the Holocene, also by morphological comparison with contemporary south Chinese and Southeast Asians. While the Laishui cranium is representative of a modern human morphology, some features (low frontal bone, strong browridge) are archaic (Etler 1996; Keates 2003). The modern human from Huanglong also combines mostly modern with a few archaic features, for example, thick cranial bones (Wang and Li 1983; Wu and Poirier 1995:175). Wang and Bräuer (1984; see also Wu and Poirier 1995:175) concluded that Huanglong is more similar to Paleolithic crania from Europe and more archaic compared to modern Chinese. The Huanglong frontal squama thickness (central squama, $10.3 \mathrm{~mm}$ ) is greater than the thickness measured on 2 archaic H. sapiens crania (Dali: $9.0 \mathrm{~mm}$; Jinniushan: $5.0 \mathrm{~mm}$ ) and the Hexian H. erectus cranium $(7.0 \mathrm{~mm}$ ) (for measurements, see Wu and Poirier 1995). Wang and $\mathrm{Li}$ (1983) discount the hypothesis of a transitional or hybrid human population based on the modern and archaic characteristics because of a lack of evidence of other human subspecies during the Chinese Late Pleistocene. Wu et al.'s (2004) study of the Shuidonggou parietal identified 2 archaic features not normally found in modern humans (including a more heavily muscled temporalis). A few archaic features have also been identified at Maludong (for instance, a projecting browridge; $\mathrm{Wu}$ and Poirier 1995:207). 
But are these so-called archaic traits indicative of an earlier age than indicated in some cases by the absolute dates or are these retentions? A case in point is the recent direct ${ }^{14} \mathrm{C}$ dating of some human material in Europe. This has shown that an archaic morphology, or one with some archaic features, does not necessarily indicate an old age. For example, the morphology of Hahnöfersand 1 (northern Germany) indicated a Late Pleistocene age for this calotte (Bräuer 1989:136), but direct dating produced a Holocene age (Street and Terberger 2004).

\section{CONCLUSION}

As long as human fossils are not directly dated, their chronology is uncertain. U-series dates are no substitute for direct dating of human fossils. Therefore, to end the uncertainty about the age of most early modern humans in China, Korea, and Japan, direct dating should be attempted, preferentially by AMS ${ }^{14} \mathrm{C}$, because of the small samples required. Without direct dating of the human fossils themselves, I would argue that the chronology of Pleistocene modern humans will remain little more than guesswork, lacking scientific credibility. Direct dating of undated human fossil sites could also potentially contribute to a better chronology of the associated non-human fauna.

\section{ACKNOWLEDGMENTS}

I am grateful to Drs Vyacheslav N Dementiev and Yaroslav V Kuzmin, Institute of Geology \& Mineralogy, Siberian Branch of the Russian Academy of Sciences, Novosibirsk, Russia, for designing Figure 1. I thank Dr Minoru Yoneda, University of Tokyo, Japan, for information about the ShirahoSaonetabaru Cave and the reviewers for their helpful comments.

\section{REFERENCES}

Aigner JS. 1981. Archaeological Remains in Pleistocene China. Munich: Verlag C.H. Beck. 351 p.

Aitken MJ. 1994. Science-Based Dating in Archaeology. London: Longman. $274 \mathrm{p}$.

An Z. 1983. Carbon-14 dating and its problems of the Late Paleolithic of China. Acta Anthropologica Sinica 2(4):342-51. In Chinese with English abstract.

An Z. 1991. Radiocarbon dating and the prehistoric archaeology of China. World Archaeology 23(2):193200.

Baba H, Endo B. 1982. Postcranial skeleton of the Minatogawa man. In: Suzuki, H, Hanihara K, editors. The Minatogawa Man. Tokyo: University of Tokyo Press. p 61-195.

Barnard N. 1972. The first radiocarbon dates from China. Monographs on Far Eastern History 8. Canberra: Australian National University.

Barton L, Brantingham PJ, Ji D. 2007. Late Pleistocene climate change and Paleolithic cultural evolution in Northern China: implications from the Last Glacial Maximum. Developments in Quaternary Sciences 9: 105-28.

Brantingham PJ, Krivoshapkin AI, Li J, Tserendagva Y. 2001. The initial Upper Paleolithic in Northeast Asia. Current Anthropology 42:735-47.

Bräuer G. 1989. The evolution of modern humans: a comparison of the African and non-African evidence. In: Mellars P, Stringer C, editors. The Human Revolution. Edinburgh: Edinburgh University Press. p 123-54.
Brown P. 1998. The first Mongoloids: another look at Upper Cave 101, Liujiang and Minetogawa 1. Acta Anthropologica Sinica 17(4):255-75. In Chinese with English abstract.

Cao P. 1984. A paleoanthropological and Paleolithic site found in Guizhou. Acta Anthropologica Sinica 3:1823. In Chinese with English abstract.

Cao Z. 1978. Paleolithic site Xiaohuidong in Shuicheng, Guizhou. Vertebrata PalAsiatica 16(1):67-72. In Chinese.

Cao Z. 1982. On the Palaeolithic artifacts from Maomaodong (the rock shelter site), Guizhou Province. Vertebrata PalAsiatica 20:155-64. In Chinese.

CASS (The Institute of Archaeology, Chinese Academy of Social Sciences). 1991. Radiocarbon Dates in Chinese Archaeology 1965-1991. Beijing: Cultural Relics Publishing House. 487 p. In Chinese with English abstract.

Chen D, Qi G. 1978. Fossil human and associated mammalian fauna from Xizhou, Yunnan. Vertebrata PalAsiatica 16(1):33-46. In Chinese.

Chen T, Yuan S. 1988. Uranium-series dating of bones and teeth from Chinese Palaeolithic sites. Archaeometry 30(1):59-76.

Chen T, Zhang Y. 1991. Palaeolithic chronology and possible coexistence of Homo erectus and Homo sapiens in China. World Archaeology 23:147-54.

Chen T, Yuan S, Gao S. 1984. The study on uranium-series dating of fossil bones and an absolute age se- 
quence for the main Paleolithic sites of North China. Acta Anthropologica Sinica 3(3):259-69. In Chinese with English abstract.

Chen T, Hedges REM, Yuan Z. 1989. Accelerator radiocarbon dating for Upper Cave of Zhoukoudian. Acta Anthropologica Sinica 8(3):216-21. In Chinese with English abstract.

Chen T, Hedges REM, Yuan Z. 1992. The second batch of accelerator radiocarbon dates for Upper Cave site of Zhoukoudian. Acta Anthropologica Sinica 11(2): 112-6. In Chinese with English abstract.

Chia L [Jia L], Woo J [Wu R]. 1959. Fossils of a human skull base of late Paleolithic stage from Chilinshan, Leipin district, Kwangsi, China. Vertebrata PalAsiatica 3(1):37-40. In Chinese.

Chia L, Gai P, Li Y. 1964. New materials from the Shuidonggou Palaeolithic site. Vertebrata PalAsiatica 8(1):75-83. In Chinese.

Chia L, Kai P [Gai P], You Y. 1972. Report of excavation in Shi Yu - a Palaeolithic site. Kaogu 1:39-60. In Chinese.

Chiu C-L. 1955. Notes on the application of the fluorine dating method to the dating of some fossil human remains from China. Acta Palaeontologica Sinica III(4):323-9. In Chinese with English abstract.

Dong X, Fan X. 1996. Note on fossil human teeth from Fox Cave at Qingliu. Acta Anthropologica Sinica 15(4):315-9. In Chinese with English abstract.

Etler DA. 1996. The fossil evidence for human evolution in Asia. Annual Review of Anthropology 25:275-301.

Gao X, Li J, Madsen DB, Brantingham PJ, Elston RG, Bettinger RL. 2002. New ${ }^{14} \mathrm{C}$ dates for Shuidonggou and related discussions. Acta Anthropologica Sinica 21(3):211-8. In Chinese with English abstract.

Geological Survey of Ningxia Museum and Ningxia Geological Bureau. 1987. The excavation report of Shuidonggou, 1980. Kaoguxuebao 4:439-49. In Chinese.

Han D, Zhang S. 1978. A human fossil canine found in Jiande and new data of Quaternary mammals in Zhejiang. Vertebrata PalAsiatica 16(4):255-63. In Chinese.

Hanihara K. 1995. The Origins and Formation of the Japanese. Kyoto: Jinbun Shoin. In Japanese.

Hedges REM, Housley RA, Law IA, Perry C, Hendy E. 1988. Radiocarbon dates from the Oxford AMS system: Archaeometry Datelist 8. Archaeometry 30(2): 291-305.

Hedges REM, Housley RA, Bronk CR, van Klinken GJ. 1992. Radiocarbon dates from the Oxford AMS system: Archaeometry Datelist 14. Archaeometry 34(1): 141-59.

Higham TFG, Jacobi RM, Bronk Ramsey C. 2006. AMS radiocarbon dating of ancient bones using ultrafiltration. Radiocarbon 48(2):179-95.

Hu S. 1995. Paleolithics excavated in Zhangkou Cave, Jiuxiang, Yiliang County. Acta Anthropologica Sinica 14(1):21-31. In Chinese with English abstract.

Huang W, Wei Q. 1981. Salawusuhe de Hetao ren jiqi wenhua [Salawusu River Ordos man and associated cultures]. In: Yikezhaomen County Relics Station, editor. Ordos Wenwu Kaogu Lunwen Ji. Hohhot: Nei Mongol Cultural Relics Bureau. p 24-32. In Chinese.

Huang W, Zheng S. 1982. An Upper Pleistocene human tooth and mammalian fossils from Zhangwu, Shaanxi. Acta Anthropologica Sinica 1(1):14-7. In Chinese with English abstract.

Huang W, Xu Z, Zheng S, Lu Z, Huang Y, Gu Y, Dong W. 2000. Preliminary report on the Paleolithic site of Migong Cave, Wushan County, Chongqing. Longgupo Prehistoric Culture 2:7-63. In Chinese with English abstract.

Huang X. 1989. A calva of Homo sapiens from Chuandong, Puding, Guizhou. Acta Anthropologica Sinica 8:379-80. In Chinese.

Ives JW, Yang Z, Beaudoin AB, Ye Q. 1994. Human presence in Heilongjiang, China, along the Late Pleistocene periphery of Beringia. Current Research in the Pleistocene 11:136-8.

IVPP (Compiling Group of the Atlas, Institute of Vertebrate Paleontology and Paleoanthropology). 1980. Atlas of Primitive Man in China. Beijing: Science Press. $174 \mathrm{p}$.

Jia L, editor. 1999. Chronicle of Zhoukoudian (19271937). Shanghai: Shanghai Scientific \& Technical Publishers.

Jia LP, Huang WW. 1990. The Story of Peking Man. Beijing: Foreign Languages Press; Hong Kong: Oxford University Press. $270 \mathrm{p}$.

Jiang P. 1982. A fossil human tooth from Jilin Province. Vertebrata PalAsiatica 20:64-71. In Chinese with English abstract.

Kamminga J, Wright RVS. 1988. The Upper Cave at Zhoukoudian and the origins of the Mongoloids. Journal of Human Evolution 17(8):739-67.

Keates SG. 2003. Chinese Homo sapiens in the context of Eurasian hominid dispersal. In: Burdukiewicz JM, Fiedler L, Heinrich W-D, Justus A, Brühl E, editors. Erkenntnisjäger - Kultur und Umwelt des frühen Menschen, Festschrift für Dietrich Mania. Halle (Saale): Veröffentlichungen des Landesamtes für Archäologie Sachsen-Anhalt - Landesmuseum für Vorgeschichte 57/I:297-302.

Keates SG, Hodgins GWL, Kuzmin YV, Orlova LA. 2007. First direct dating of a presumed Pleistocene hominid from China: AMS radiocarbon age of a femur from the Ordos Plateau. Journal of Human Evolution 53(1):1-5.

Kondo M, Matsu'ura S. 2005. Dating of the Hamakita human remains from Japan. Anthropological Science 113:155-61.

Li H-J, Wu X-J. 2007. Sex determination of the human fossil cranium from Jingchuan. Acta Anthropologica Sinica 26(2):107-15. In Chinese with English abstract.

Li W, Zhang Z, Gu Y, Lin Y, Yan F. 1982. A fauna from Lianhua Cave, Dantu, Jiangsu. Acta Anthropologica Sinica 1(2):169-79. In Chinese with English abstract. 
Li X, Zhang S. 1984. Paleoliths discovered in Ziyang Man Locality B. Acta Anthropologica Sinica 3:21524. In Chinese with English abstract.

Li Y, Wu M, Peng S, Zhou S. 1984. Human tooth fossils and some mammalian remains from Tobo, Liujiang, Guangxi. Acta Anthropologica Sinica 3(4):322-9. In Chinese with English abstract.

Licent E, Teilhard de Chardin P. 1925. Le Paléolithique de la Chine. L'Anthropologie XXXV:201-34.

Licent E, Teilhard de Chardin P, Black D. 1927. On a presumably Pleistocene human tooth from the Sjarraosso-gol (South-Estern Ordos) deposits. Bulletin of the Geological Society of China V:285-90.

Liu W, Wu X-J, Wang S. 2006. Some problems for the Late Pleistocene human cranium found in Liujiang of South China based on morphological analysis. Acta Anthropologica Sinica 25(3):177-94. In Chinese with English abstract.

Liu W, Wu X-Z, Li Y-Y, Deng C-L, Wu X-J, Pei S-W. 2008. Evidence of fire use of late Pleistocene humans from the Huanglong Cave, Hubei Province, China. Chinese Science Bulletin 54(2):256-64.

Liu Y. 1986. The paleoliths newly discovered at the Xigou site, Quwo county, Shanxi Province. Acta Anthropologica Sinica 5(4):325-35. In Chinese with English abstract.

Liu Y, Huang W, Lin Y. 1984. Human fossil and Paleolithic remains from Jinchuan, Gansu. Acta Anthropologica Sinica 3(1):11-8. In Chinese with English abstract.

Madsen DB, Li J, Brantingham PJ, Gao X, Elston RG, Bettinger RL. 2001. Dating Shuidonggou and the Upper Palaeolithic blade industry in North China. Antiquity 75:706-16.

Management Committee of Cultural Relics of Heilongjiang Province; Bureau of Affairs of Harbin Municipality, Northwestern Expedition of the Institute of Vertebrate Paleontology and Paleoanthropology, Academia Sinica. 1987. Yanjiagang, A Late Paleolithic Campsite in Harbin. Beijing: Wenwu Press. In Chinese with English abstract.

Matsu'ura S. 1982. Relative dating of the Minatogawa man by fluorine analysis. In: Suzuki H, Hanihara K, editors. The Minatogawa Man. Tokyo: University of Tokyo Press. p 205-8.

Matsu'ura S. 1996. A chronological review of Pleistocene human remains from the Japanese archipelago. In: Omoto K, editor. Interdisciplinary Perspectives on the Origins of the Japanese. Kyoto: International Research Center for Japanese Studies. p 181-97.

Matsu'ura S, Kondo M. 2000. How far do the Palaeolithic hominid remains of Japan date back? Dating methods for fossil bones. In: Mabuchi H, Tominaga T, editors. Kokogaku to Kagaku wo Musubu. Tokyo: University of Tokyo Press. p 135-67. In Japanese.

Matsu'ura S, Kondo M. 2001. Dating of the Mikkabi human remains from Japan. Anthropological Science 109(4):275-88.
Museum of Liaoning Province and Museum of Benxi City. 1986. Miaohoushan: A Site of Early Paleolithic in Benxi County, Liaoning. Beijing: Wenwu Press. In Chinese with English abstract.

Nakagawa R, Doi N, Nishioka Y, Nunami S, Yamauchi H, Fujita M, Yamazaki S, Yamamoto M, Katagiri C, Mukai H, Matsuzaki H, Gakuhari T, Takigami M, Yoneda M. 2010. Pleistocene human remains from ShirahoSaonetabaru Cave on Ishigaki Island, Okinawa, Japan, and their radiocarbon dating. Anthropological Science. doi:10.1537/ase.091214.

Norton CJ. 2000. The current state of Korean paleoanthropology. Journal of Human Evolution 38(6):80325.

Ono A, Oda S, Matsu'ura S. 1999. Palaeolithic cultures and Pleistocene hominids in the Japanese islands: an overview. The Quaternary Research 38(3):177-83.

Pan Y-J, Shen G-J, Fang Y-S. 2002. U-series dating of fossil teeth from Lianhua Cave in Zhenjiang, Jiangsu Province. Acta Anthropologica Sinica 21(2):155-7. In Chinese with English abstract.

Pei J. 1985. Thermoluminescence dating of the Peking Man site and other caves. In: Institute of Vertebrate Paleontology and Paleoanthropology, Academia Sinica, editor. Multidisciplinary Study of the Peking Man Site at Zhoukoudian. Beijing: Science Press. p 25660. In Chinese.

Pei W. 1934. A preliminary report on the Late-Palaeolithic cave of Choukoutien. Bulletin of the Geological Society of China XIII(2):327-50.

Pei W. 1939. The Upper Cave Industry of Choukoutien. Palaeontologia Sinica N.S. C. No. 10. Peking: Geological Survey of China. 141 p.

Pei W. 1957a. Introductory notes on the discovery of human and vertebrate fossils in Tzeyang District, Szechuan Province. In: Pei W, Woo J-K. Tzeyang Man. Memoirs of the Institute of Vertebrate Paleontology and Paleoanthropology. Series A 11:1-12. In Chinese and English.

Pei W. 1957b. Mammalian fossils from Tzeyang District, Szechuan Province. In: Pei W, Woo J-K. Tzeyang Man. Memoirs of the Institute of Vertebrate Paleontology and Paleoanthropology. Series A 11:51-68. In Chinese and English.

Pei W. 1957c. Appendix: Tzeyang bone awl. In: Pei W, Woo J-K. Tzeyang Man. Memoirs of the Institute of Vertebrate Paleontology and Paleoanthropology. Series A 11:50. In English.

Peng S, Zhou S, Wang W. 1987. Human fossils and associated fauna found in Nalai Cave, Longlin, Guangxi. Shiqianyanjiu 4:43-6. In Chinese.

Qiu L, Song F, Wang L. 1986. A fossil human tooth from Fengkai, Guangdong. Acta Anthropologica Sinica 5: 311-3. In Chinese with English abstract.

Qiu Z, Zhang Y, Hu S. 1985. Human tooth and paleoliths found at locality 2 of Longtanshan, Chengong, Kunming. Acta Anthropologica Sinica 4(3):233-41. In Chinese with English abstract. 
Serizawa C. 1979. Cave sites in Japan. World Archaeology 10(3):340-9.

Shang H, Wei Q, Wu X-H. 2006. An issue on the date of fossil human remains from Salawusu, Inner Mongolia. Acta Anthropologica Sinica 25(1):82-6. In Chinese with English abstract.

Shang H, Tong H, Zhang S, Chen F, Trinkaus E. 2007. An early modern human from Tianyuan Cave, Zhoukoudian, China. Proceedings of the National Academy of Sciences of the USA 104(16):6573-8.

Shen G. 1993. Uranium-series ages of speleothems from Guizhou Paleoltihic sites and their paleoclimatic implications. In: Jablonski N, editor. Evolving Landscapes and Evolving Biotas of East Asia since the Mid-Tertiary. Hong Kong: Centre of Asian Studies, The University of Hong Kong. p 275-82.

Shen GJ, Wang W, Wang Q, Pan PJ. 2001a. U-series dating of hominid site Ganqian Cave at Tubo, Liujiang, Guangxi in South China. Acta Anthropologica Sinica 20(3):238-44. In Chinese with English abstract.

Shen GJ, Wang JQ, Xu BX, Kuang Y, Zhao JX. 2001b. U-series dating of Bailiandong site in Liuzhou, Guangxi, South China. Journal of Stratigraphy 25: 325-30.

Shen G, Wang W, Wang Q, Zhao J, Collerson K, Zhou C, Tobias PV. 2002a. U-series dating of Liujiang hominid site in Guangxi, Southern China. Journal of Human Evolution 43(6):817-29.

Shen GJ, Wang W, Wang Q. 2002b. U-series dating of Ganqian Cave in Guangxi and its anthropological implications. Acta Anthropologica Sinica 21 (Supplement):78-87. In Chinese with English abstract.

Shen G, Li J, Ji X. 2005. U-series dating of Zhangkou Cave in Yiliang, Yunnan Province: evidence for human activities in China during 40-100 ka. Chinese Science Bulletin 4:355-9.

Shen G, Wang W, Cheng H, Edwards RL. 2007. Mass spectrometric U-series dating of Laibin hominid site in Guangxi, southern China. Journal of Archaeological Science 34(12):2109-14.

Song F, Zhang Z, Deng Z, Zhen X, Cheng Q. 1991. The study of the fauna and the human teeth from Tongzhongyan in Fengkai, Guangdong. In: The Fengkai County Museum et al., editors. Treatises in Commemoration of the 30th Anniversary of the Discovery of Huangyan Cave Site. Guandong: Guangzhou Travel and Tourism Press. p 28-40. In Chinese.

Street M, Terberger T. 2004. The radiocarbon chronology of the German Upper Palaeolithic: fifteen years of cooperation with ORAU. In: Higham T, Bronk Ramsey C, Owen C, editors. Radiocarbon and Archaeology. Oxford University School of Archaeology Monographs 62. Oxford: Oxford University School of Archaeology. p 281-302.

Suzuki H. 1962. Human skeletal remains of Mikkabi man. Journal of the Anthropological Society of Nippon 70:1-20 (in Japanese), 46-8 (English summary).

Suzuki H. 1982. Skulls of the Minatogawa man. In: Su- zuki H, Hanihara K, editors. The Minatogawa Man. Tokyo: University of Tokyo Press. p 7-49.

Suzuki H, Tanabe G. 1982. Introduction. In: Suzuki H, Hanihara K, editors. The Minatogawa Man. Tokyo: University of Tokyo Press. p 1-5.

Takai F. 1962. Vertebrate fossils from the Tadaki formation. Journal of the Anthropological Society of Nippon 70:36-40, 46-8. In Japanese with English summary.

Takamiya H, Kin M, Suzuki M. 1975. Excavation report of the Yamashita-cho Cave site, Naha-shi, Okinawa. Journal of the Anthropological Society of Nippon 83: 125-30. In Japanese with English summary.

Tanabe G. 1962. Fluorine contents of human bones from Pleistocene deposits of Mikkabi. Journal of the Anthropological Society of Nippon 70:36-40, 46-8. In Japanese with English summary.

Taylor RE. 1992. Radiocarbon dating of bone: to collagen and beyond. In: Taylor RE, Long A, Kra RS, editors. Radiocarbon After Four Decades, an Interdisciplinary Perspective. New York: Springer Verlag. p 375-402.

Teilhard de Chardin P, Licent E. 1924. On the discovery of a Palaeolithic industry in Northern China. Bulletin of the Geological Society of China 3(1):45-50.

The Laboratory of IA and of IVPP, Academia Sinica. 1976. The carbon-dating of bone specimens. Kaogu 1: 28-30. In Chinese.

The Quaternary Section of the Chengtu Institute of Geology. 1974. The geological date of the fossil skull of the Tzuyang Man. Kaogu Xuebao 2:111-23. In Chinese with English abstract.

Tong H-W, Liu J-Y, Zhang S-Q. 2004. Large mammal fossils from Tianyuan Cave, a human fossil site of End-Pleistocene age recently discovered near Zhoukoudian. Acta Anthropologica Sinica 23(3):213-23. In Chinese with English abstract.

Tong H-W, Shang H, Zhang S-Q, Liu J-Y, Chen, F-Y, Wu X-H, Li Q. 2006. Mammalian biostratigraphy of Tianyuan Cave compared with that of Upper Cave at Zhoukoudian. Acta Anthropologica Sinica 25(1):6881. In Chinese with English abstract.

Trinkaus E, Ruff CB. 1996. Early modern human remains from eastern Asia: the Yamashita-cho 1 immature postcrania. Journal of Human Evolution 30(4): 299-314.

Wang L. 1989. Chronology in Chinese palaeoanthropology. In: Wu R, Wu X, Zhang S, editors. Early Humankind in China. Beijing: Science Press. p 392-409. In Chinese.

Wang L, Bräuer G. 1984. A multivariate comparison of the human calva from Huanglong County, Shaanxi Province. Acta Anthropologica Sinica 3(4):313-21. In Chinese with English abstract.

Wang L, Li Y. 1983. On a fossil human calva unearthed from Huanglong county, Shaanxi Province. Acta Anthropologica Sinica 2(4):315-9. In Chinese with English abstract.

Wang L, Peng S, Chen Y. 1982. On the human fossils and 
stone artifacts found in Baojiyan Cave, Guilin. Acta Anthropologica Sinica 1(1):30-5. In Chinese with English abstract.

Wang W, Mo J-Y. 2004. Human fossil teeth newly discovered in Nanshan Cave of Fusui, Guangxi. Acta Anthropologica Sinica 23(2):130-7. In Chinese with English abstract.

Wang W, Huang Q, Zhou S. 1999. New found human fossils in Tubo, Liujiang, Guangxi. Longgupo Shiqian Wenhua Zhi 1:104-8. In Chinese with English abstract.

Wei Q. 2005. History of scientific research in Xarusgol River. Wenwu Chunqiu 5:1-20. In Chinese.

Wolpoff MH. 1999. Paleoanthropology. 2nd edition. Boston: McGraw-Hill. 878 p.

Woo J-K [Wu R]. 1957. Fossil human skull from Tzeyang District, Szechuan Province. In: Pei W, Woo J-K. Tzeyang Man. Memoirs of the Institute of Vertebrate Paleontology and Paleoanthropology. Series A 11: 13-49. In Chinese and English.

Woo J-K [Wu R]. 1959. Human fossils found in Liukiang, Kwangsi, China. Vertebrata PalAsiatica 3(3): 109-18. In Chinese with English abstract.

Wu M. 1989. Late Homo sapiens of China. In: Wu R, Wu $\mathrm{X}$, Zhang S, editors. Early Humankind in China. Beijing: Science Press. p 42-61. In Chinese.

Wu X. 1961. Study on the Upper Cave man of Choukoutien. Vertebrata PalAsiatica 5(3):181-210. In Chinese with English abstract.

Wu X. 1988. The relationship between Upper Paleolithic human fossils of China and Japan. Acta Anthropologica Sinica 7:235-8. In Chinese with English abstract.

Wu X, editor. 2006. Yunxi Man - Huanglongdong Site Excavation. Beijing: Science Press. 271 p. In Chinese with English abstract.

Wu X, Poirier FE. 1995. Human Evolution in China. Oxford: Oxford University Press. 317 p.

Wu X, Wang L. 1985. Chronology in Chinese Palaeoanthropology. In: Wu R, Olsen JW, editors. Palaeoanthropology and Palaeolithic Archaeology in the People's Republic of China. London: Academic Press. p 29-51.

Wu X, Zhang Z. 1985. Homo sapiens remains from Late Palaeolithic and Neolithic China. In: Wu R, Olsen JW, editors. Palaeoanthropology and Palaeolithic Archaeology in the People's Republic of China. London: Academic Press. p 107-33.

Wu X, Zong G. 1973. Late Pleistocene human tooth and mammalian fossils from Wuzhutai, Xintai, Shandong. Vertebrata PalAsiatica 11:105-6. In Chinese.

Wu X, Zhao Z, Yuan Z, Shen J. 1962. Report on the paleoanthropological expedition of the northeastern part of Kwangsi. Vertebrata PalAsiatica 6:408-14. In Chinese.

Wu X, Wu L, Wang Z. 2004. A human parietal fossil found at the Shuidonggou site, Ningxia, China. Anthropological Science 112(1):83-9.

Wu X, Liu W, Gao X, Yin G. 2006. Huanglong Cave, a new late Pleistocene hominid site in Hubei Province,
China. Chinese Science Bulletin 51(20):2493-9.

Wu X-Z, Wu X-J, Chen M-H, Qu S-M, Pei S-W, Liu W. 2007. The 2006 excavation of Huanglong Cave in Yunxi County, Hubei. Acta Anthropologica Sinica 26(3):193-205. In Chinese with English abstract.

Wu Z, Shun B. 1989. A preliminary study of the Upper Palaeolithic cave sites from Dangcheng, Heshun County, Shanxi Province. Acta Anthropologica Sinica 8(1):39-48. In Chinese with English abstract.

Xie J, Zhang ZB, Yang FX. 1987. Human fossils found at Wushan, Gansu Province. Shiqian Yanjiu 4:47-51. In Chinese.

Yang D, editor. 1989. Atlas of the People's Republic of China. Beijing: Foreign Languages Press and China Cartographic Publishing House.

Yokoyama Y. 1992. Quest for the origins of modern human. Kagaku 62:195-6. In Japanese.

You Y-Z, Xu Q-Q, Li Y, Ho C-K. 1986. Seasonality and site structure of Late Paleolithic sites from Northeast China. Current Research in the Pleistocene 3:97-102.

You Y, Dong X, Chen C, Fan X. 1989. A fossil human tooth from Qingliu, Fujian. Acta Anthropologica Sinica 8(3):197-202. In Chinese with English abstract.

Yu H. 1988. A brief study of Late Palaeolithic localities at Xuetian village of Wuchang County, Heilongjiang Province. Acta Anthropologica Sinica 7(3):255-62. In Chinese with English abstract.

Yu J. 1984. Fossil man and cultural artifacts from Chuandong, Puding County, Guizhou Province. Journal of Nanjing University (Natural Science) 1:145-68. In Chinese with English abstract.

Yuan S, Chen T, Gao S. 1983. Uranium series dating of “Ordos Man” and "Sjara-osso-gol Culture.” Acta Anthropologica Sinica 2(1):90-4. In Chinese with English abstract.

Yuan S, Chen T, Gao S. 1986. Uranium series chronological sequence of some Palaeolithic sites in South China. Acta Anthropologica Sinica 5(2):179-90. In Chinese with English abstract.

Yuan S, Zhou G, Guo Z, Zhang Z, Gao S, Li K, Wang J, Liu K, Li B, Lu X. 1995. ${ }^{14} \mathrm{C}$ AMS dating the transition from the Paleolithic to the Neolithic in South China. Radiocarbon 37(2):245-9.

Yunnan Provincial Museum. 1977. A preliminary study on a human skull from Lijiang, Yunnan. Vertebrata PalAsiatica 15:157-61. In Chinese.

Yunnan Provincial Museum. 1991. On Materials of Human Origins and Prehistoric Culture in Yunnan. Kunming: Yunnan Renmin Press. In Chinese.

Zhang X, Li C. 1982. Human fossil discovered in Longlin, Guangxi. Acta Anthropologica Sinica 1:199. In Chinese with English abstract.

Zhang X, Zheng L, Yang L, Bao Z. 1991. Human fossils and the paleoculture from Mengzi. In: Yunnan Provincial Museum, editor. On Materials of Human Origin and Prehistoric Culture of Yunnan. Kunming: Yunnan Renming Press. p 234-46. In Chinese.

Zhang X-F, Ji X-P, Shen G-J. 2004. U-series dating of 
fossil teeth from Xianren Cave in Xichou, Yunnan Province. Acta Anthropologica Sinica 23(1):88-92. In Chinese with English abstract.

Zhang Y. 1983. On some problems of the Upper Paleolithic culture in southern China. Acta Anthropologica Sinica 2:218-30. In Chinese with English abstract.

Zhang Y. 1986. The dental remains of early Homo sapiens found in China. Acta Anthropologica Sinica 5(2): 103-13. In Chinese with English abstract.

Zhao Z, Liu X, Wang L. 1981. Human fossils and associated fauna of Jiulengshan Hill, Guangxi. Vertebrata PalAsiatica 19(1):45-54. In Chinese.

Zheng L. 1985. A fossil human tooth from Zhaotong,
Yunnan. Acta Anthropologica Sinica 4(2):105-8. In Chinese with English abstract.

Zhou G. 1994a. On the Bailiandong culture [unpublished manuscript]. $7 \mathrm{p}$.

Zhou G. 1994b. A further study of Bailiandong site. In: Zhou G, chief editor. Relationship between Chinese and Japanese Ancient Men and Prehistoric Cultures. International Symposium. Beijing: China International Radio Press. p 263-8. In Chinese and English.

Zhou W, Chen M. 2009. Development of radiocarbon dating in China over the past 50 years. Radiocarbon 51(1):91-107. 